HYDROGEOLOGY AND RESULTS OF AQUIFER TESTS

IN THE VICINITY OF A HAZARDOUS-WASTE

DISPOSAL SITE NEAR BYRON, ILLINOIS

By Robert T. Kay, David N. Olson, and Barbara J. Ryan

U.S. GEOLOGICAL SURVEY

Water-Resources Investigations Report 89-4081

Prepared in cooperation with the

U.S. ENVIRONMENTAL PROTECTION AGENCY

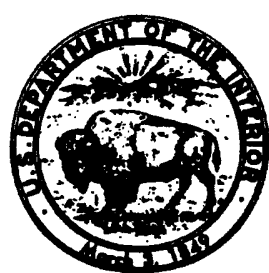

Urbana, Illinois

July 1989 
DEPARTMENT OF THE INTERIOR

MANUEL LUJAN, JR., Secretary

U.S. GEOLOGICAL SURVEY

Dallas L. Peck, Director

For additional information

write to:

District Chief

U.S. Geological survey

4 th Floor

102 East Main Street

Urbana, IL 61801
Copies of this report can be purchased from:

U.S. Geological Survey Books and Open-File Reports section Federal Center Box 25425

Denver, CO 80225 


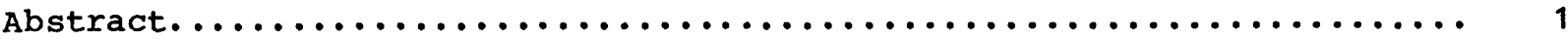

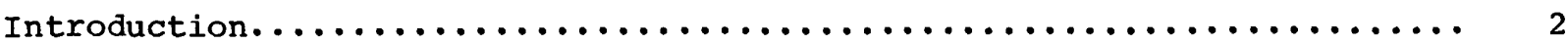

Purpose and scope....................................4

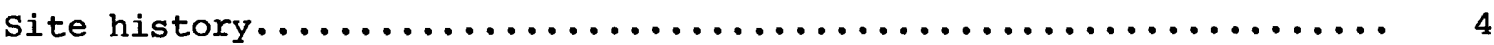

Well descriptions.....................................4

Acknowledgments......................................

Hydrogeology ..........................................

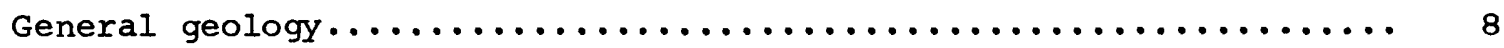

Hydrology ............................................ 14

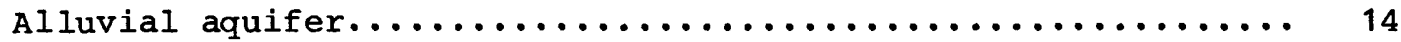

Galena-platteville aquifer............................ 14

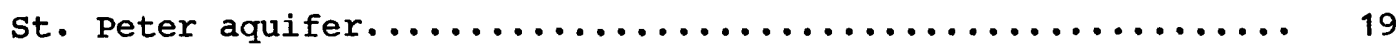

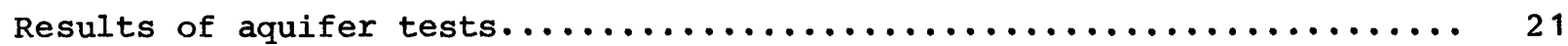

step-drawdown tests................................. 21

Constant-discharge tests...................................

Galena-platteville aquifer test....................... 24

St. Peter aquifer test.............................. 41

summary and conclusions...................................48

References.................................................. ..... 49

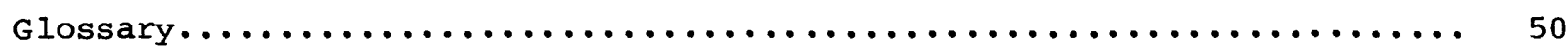

Appendix 1: Results of geophysical logging....................

\section{ILLUSTRATIONS}

\section{Figures}

1-3. Maps showing:

1. Location of study area, salvage yard, and fracture

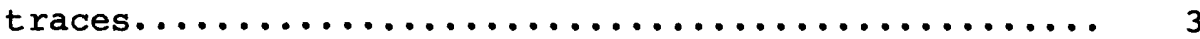

2. Location of observation wells in the study area....... 6

3. Location of wells within the salvage yard........... 7

4. Diagram showing natural-gamma log, lithologic log, and generalized stratigraphic section for well MW-20......... 9

5. Generalized geologic column showing stratigraphy of the ordovician rocks and quaternary deposits in the

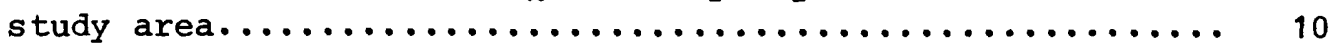

6. Map showing location of lines of section in the study area... 12

7. Diagram showing geologic section $\mathrm{C}-\mathrm{C}^{\prime} \ldots \ldots \ldots \ldots \ldots \ldots \ldots \ldots$ 
8-11. Maps showing:

8. Average water-table altitude during the 1986

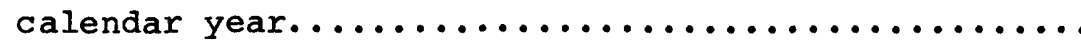

9. Water-table altitude at the salvage yard, May 18-19, 1987.............................

10. Water-level altitude in wells open to the st. Peter aquifer, May 18-19, 1987..................... 20

11. Location of wells monitored during the aquifer tests.................................

12. Diagram showing natural-gamma log and three-arm caliper

log for observation well spw.....................

13. Graph showing water-level response in observation wells $\mathrm{B}-4, \mathrm{PW}-3, \mathrm{MW}-8, \mathrm{MW}-9$, and $\mathrm{PZ}-1$ during the pumping phase of the Galena-Platteville aquifer test............

14. Map showing drawdown of the water table after pumping well SPW for 1,000 minutes, Galena-Platteville aquifer

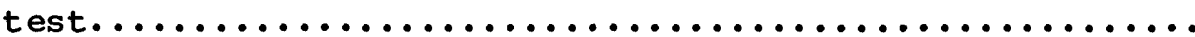

15-21. Graphs showing:

15. Water-level response in observation wells $B-3, B-5$, $\mathrm{PZ}-2$, and $\mathrm{MW}-10$ during the pumping phase of the Galena-platteville aquifer test.................

16. Water-level response in observation wells in the st. Peter aquifer during the pumping phase of the Galena-Platteville aquifer test...............

17. Logarithmic plot of drawdown as a function of time for observation well PZ-1 matched with theoretical double-porosity-type curve...................

18. Logarithmic plot of drawdown as a function of time for observation well B-4 matched with theoretical double-porosity-type curve....................

19. Logarithmic plot of drawdown as a function of time for observation well $\mathrm{PW}-3$ matched with theoretical double-porosity-type curve....................

20. Water-level response in observation wells in the st. Peter aquifer during the st. Peter aquifer test..

21. Drawdown as a function of time for observation

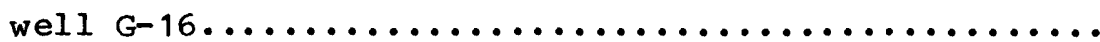

22-24. Diagrams showing:

22. Correlation of natural-gamma logs along line of

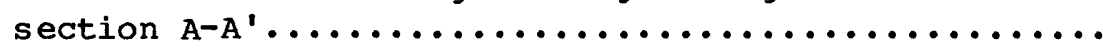

23. Correlation of natural-gamma logs along line of

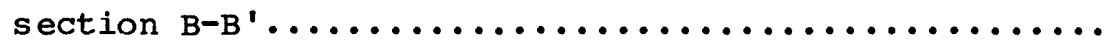

24. Neutron-log response compared to percent porosity for well $\mathrm{MW}-20 \ldots \ldots \ldots \ldots \ldots \ldots \ldots \ldots \ldots \ldots \ldots \ldots \ldots$ 
Table 1. Observation well data from the study area................

2. Time, in minutes, and corresponding drawdown, in feet, for varied discharge rates, in gallons per minute, in well SPW during the Galena-Platteville step-drawdown test of March 19, 1987...........................

3. Time, in minutes, and corresponding drawdown, in feet, for varied discharge rates, in gallons per minute, in well DPW during the st. Peter step-drawdown test of

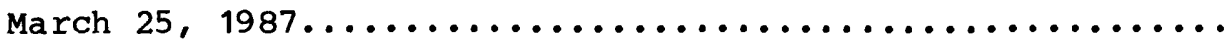

4. Time, in minutes, and corresponding drawdown, in feet, for the wells open to the Galena-Platteville aquifer during the Galena-Platteville aquifer test of

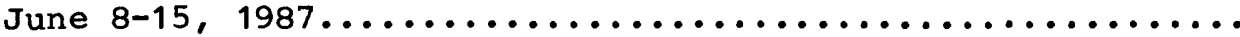

5. Estimated horizontal hydraulic conductivity, transmissivity, and specific yields from the Galena-platteville aquifer

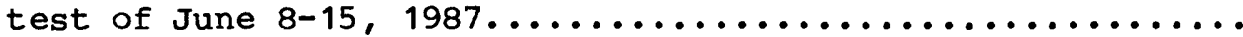

6. Time, in minutes, and corresponding drawdown, in feet, for the wells open to the st. Peter aquifer during the st. Peter aquifer test of May 27-30, 1987..............

7. Estimated horizontal hydraulic conductivity, transmissivity, storativity, and leakage through the Harmony Hill shale Member of the Glenwood Formation from the st. Peter aquifer test of May $27-30,1987 \ldots \ldots \ldots \ldots \ldots \ldots \ldots \ldots \ldots \ldots \ldots \ldots$

8. Iaboratory determined values of porosity, bulk density, grain density, and bulk specific gravity for rock samples at observation well $\mathrm{MW}-20 \ldots \ldots \ldots \ldots \ldots \ldots \ldots \ldots \ldots \ldots \ldots \ldots \ldots$ 
For the convenience of readers who may prefer to use metric (International system) units, the inch-pound values in this report may be converted by using the following factors:

\begin{tabular}{|c|c|c|}
\hline Multiply inch-pound unit & by & To obtain metric unit \\
\hline inch (in.) & 25.4 & millimeter (mm) \\
\hline foot (ft) & 0.3048 & meter (m) \\
\hline mile (mi) & 1.609 & kilometer $(\mathrm{km})$ \\
\hline acre & 4,047 & square meter $\left(\mathrm{m}^{2}\right)$ \\
\hline gallon (gal) & 3.785 & liter (L) \\
\hline gallon per minute (gal/min) & 0.06308 & liter per second (L/s) \\
\hline foot squared per day $\left(f t^{2} / d\right)$ & 0.09290 & meter squared per day $\left(\mathrm{m}^{2} / \mathrm{d}\right)$ \\
\hline $\begin{array}{l}\text { foot per day per foot } \\
{[(f t / d) / f t]}\end{array}$ & 0.3048 & $\begin{array}{l}\text { meter per day per meter } \\
{[(\mathrm{m} / \mathrm{d}) / \mathrm{m}]}\end{array}$ \\
\hline $\begin{array}{l}\text { gallon per minute per foot } \\
{[(\text { gal } / \mathrm{min}) / \mathrm{ft}]}\end{array}$ & 0.2070 & $\begin{array}{l}\text { liter per second per meter } \\
{[(\mathrm{L} / \mathrm{s}) / \mathrm{m}]}\end{array}$ \\
\hline
\end{tabular}

Sea Level: In this report "sea level" refers to the National Geodetic Vertical Datum of 1929 (NGVD of 1929)--a geodetic datum derived from a general adjustment of the first-order level nets of both the United states and Canada, formerly called sea Level Datum of 1929. 


\title{
HYDROGEOLOGY AND RESULTS OF AQUIFER TESTS IN THE VICINITY OF A HAZARDOUS-WASTE DISPOSAL SITE NEAR BYRON, ILLINOIS
}

by Robert T. Kay, David N. Olson, and Barbara J. Ryan

\author{
ABSTRACT
}

The U.S. Geological Survey, in cooperation with the U.S. Environmental Protection Agency, conducted a hydrogeologic investigation of a superfund site near Byron, Illinois. The purpose of the investigation was to determine the hydrogeologic properties that control the movement of water through the GalenaPlatteville and St. Peter aquifers. These are the primary domestic watersupply aquifers in the area.

The uppermost bedrock geologic units beneath the salvage yard are the dolomites of the Platteville and Galena Groups. These dolomites comprise the Galena-Platteville aquifer. Movement of water in the dolomites is mainly through joints, fractures, and solution openings. The dominant direction of strike of the vertical fractures in the dolomite is $\mathrm{N}$. $60^{\circ} \mathrm{W}$. in the study area. Underlying the dolomites is the Harmony Hill Shale Member of the Glenwood Formation, a semiconfining unit that separates the Galena-Platteville aquifer from the underlying St. Peter aquifer.

Ground-water flow in the study area is from the salvage yard northwestward to the Rock River. Ground water recharges from the dolomite to the St. Peter aquifer beneath the salvage yard and discharges from the Quaternary alluvial aquifer at the river.

Analysis of the Galena-Platteville aquifer-test data indicates that the calculated aquifer transmissivity ranges from 490 to 670 feet squared per day, and the calculated specific yield ranges from 0.017 to 0.140 . Aquifer-test data also indicate that the Galena-Platteville aquifer is heterogeneous and anisotropic but that the direction of maximum transmissivity tends to be parallel to the dominant vertical fracture orientation in the dolomite.

Analysis of the St. Peter aquifer-test data indicates that the calculated transmissivity of the aquifer ranges from 1,412 to 1,535 feet squared per day, storativity ranges from $5.55 \times 10^{-4}$ to $1.88 \times 10^{-3}$, horizontal hydraulic conductivity ranges from 3.4 to 3.7 feet per day, and the rate of leakage through the Harmony Hill Shale Member of the Glenwood Formation ranges from $2.35 \times 10^{-4}$ to $6.31 \times 10^{-4}$ foot per day per foot. 
In February 1987, the U.S. Geological Survey, in cooperation with the U.S. Environmental Protection Agency (USEPA), began a study of the geohydrology at a superfund site near Byron, Illinois. The site is located in rural Ogle County in northern Illinois, about $4 \mathrm{mi}$ (miles) southwest of Byron (fig. 1).

The USEPA requested the investigation to define hydraulic properties of the two primary residential-use aquifers in the area, one in the dolomite of the Galena and Platteville Groups and the other in the st. Peter sandstone (Willman and others, 1975, p. 61-80 and 218-230). The hydraulic properties of the aquifers needed to be defined to assess proposed ground-water remediation scenarios for these aquifers.

The investigation was divided into four components: collection of data on existing wells, collection of static water-level measurements, geophysical logging, and aquifer testing. Data on existing wells were used to identify wells that were suitable for geophysical logging and for monitoring during the aquifer testing. Static water-level measurements were used to determine the directions of water movement within and between the aquifers in the study area. Geophysical logging improved understanding of the rock properties in the study area. Aquifer tests were used to determine the hydraulic characteristics of the aquifers at the salvage yard.

The geophysical logging had three specific objectives:

1. Define the stratigraphy of the study area;

2. Determine the primary porosity of the rocks in the study area; and

3. Identify potential fractures in the dolomite.

Natural-gamma logs were used to define the stratigraphy in the study area; neutron logs were used to determine primary porosity. Acoustic televiewer and three-arm caliper logs were used to identify fractures in the dolomite.

The aquifer tests also had three specific objectives:

1. Determine the transmissivity, storage coefficient, and hydraulic conductivity of both aquifers;

2. Determine the primary directions of flow through the fractured bedrock in the upper aquifer; and

3. Determine the leakage rate through the Harmony Hill shale Member (willman and others, 1975, p. 64) of the Glenwood Formation, which functions as a partially confining unit between the Galena-platteville aquifer and the st. Peter aquifer.

In this report, salvage yard refers to the 20-acre area encompassing the superfund site; study area refers to that area bounded by the fault at woodland Creek to the east and the Rock River to the northwest. The boundaries of both the salvage yard and the study area are shown in figure 1. 


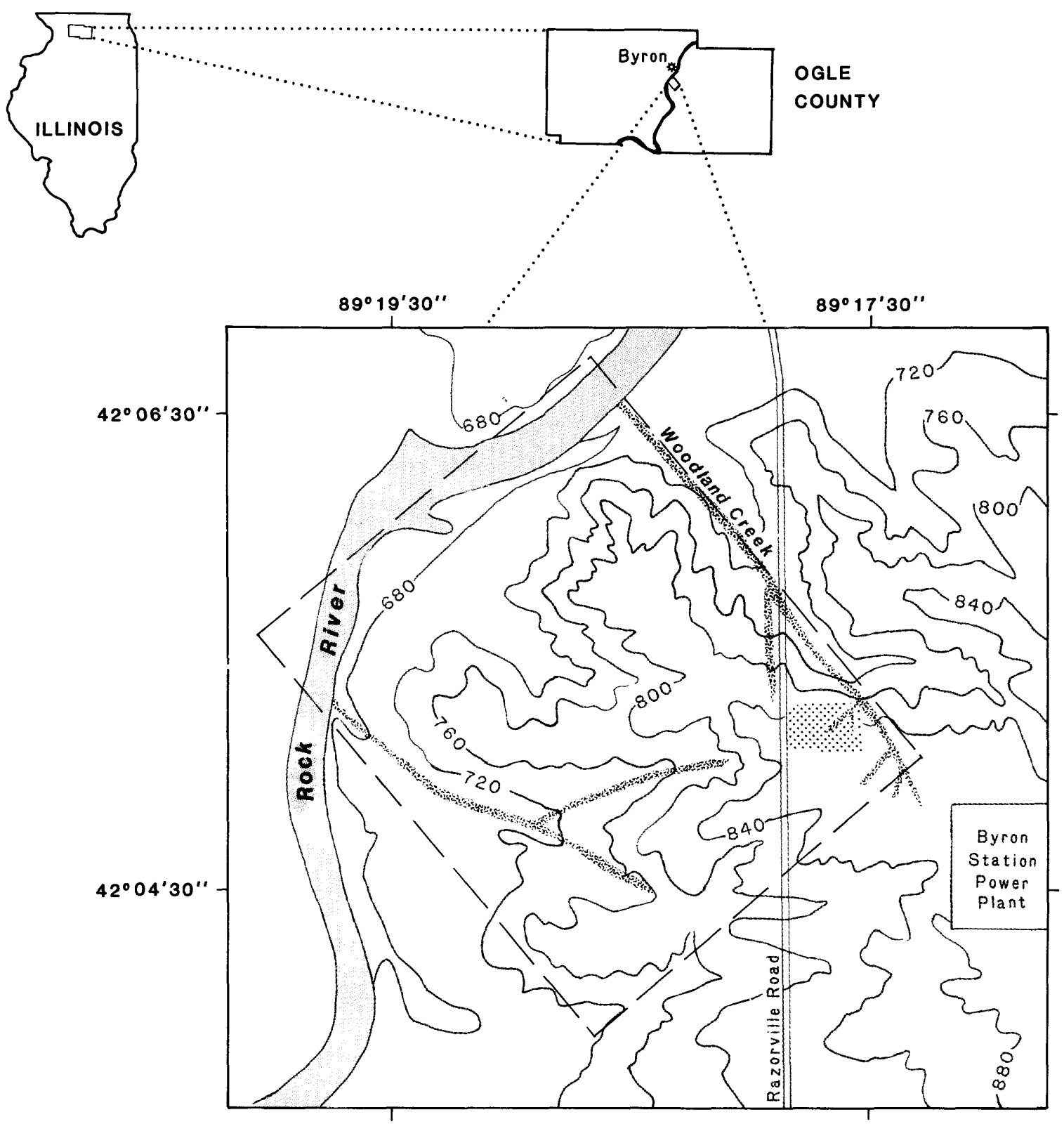

Base modified from U.S. Geological Survey Oregon, Illinois Quadrangle Map, 1922

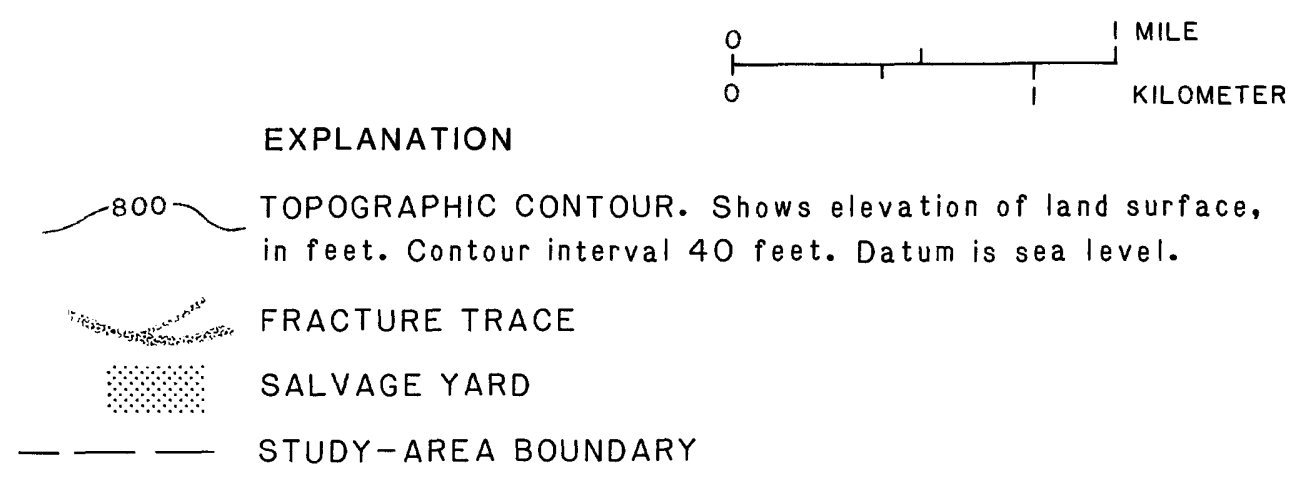

Figure 1.--Location of study area, salvage yard, and fracture traces. 
Purpose and Scope

This report describes the results of an investigation designed to determine the hydrogeologic properties that control ground-water movement in the area of a Superfund Site near Byron, Illinois. In addition to a description of the geology and hydrology of the study area, results and interpretation of static water-level measurements in the study area and the aquifer testing at the salvage yard are presented. Results and interpretation of a suite of geophysical logs run in the study area are presented in an appendix to the report.

\section{Site History}

The site was initially operated as a salvage yard and nonpermitted landfill in the 1960's; at some later date, miscellaneous industrial liquid wastes also were deposited on-site. The salvage yard was ordered closed in 1972 following a fishkill in a creek west of the site. Cyanide leachate from the salvage yard was reported to be the cause of the fishkill. During its years of operation, drums of liquid plating wastes and an extensive array of salvage objects, mainly automobile parts, were deposited at the salvage yard (CH2MHill, Inc. and Ecology and Environment, Inc., 1984, p. 2:2-2:6).

The salvage yard was placed on USEPA's Superfund National Priority List in 1982. Remedial cleanup measures, including removal of surface and buried drums and contaminated soils, were implemented at the salvage yard by the Illinois Environmental protection Agency (IEPA) in 1986. This remedial action was completed in early 1987 (Douglas Yeskis, U.S. Environmental Protection Agency, oral commun., 1987).

Cyanide and heavy metals were detected in soils, surface water, and ground water in and around the salvage yard by IEPA and USEPA. Volatile organic compounds, including perchloroethylene, trichloroethylene, and their related degradation products; plus cyanide and heavy metals have been detected in the ground-water-observation wells and residential wells beneath and downgradient from the salvage yard (D'Appolonia waste Management services, 1984, p. 7).

The property immediately west of the salvage yard also had been used for the disposal of drummed liquids. Cyanide and heavy metals were detected on and around this property in 1974. Remedial cleanup measures, which included the removal of barrels of waste and heavy-metal-contaminated soil, and treatment of cyanide-contaminated soils were implemented on the adjacent property in 1974-75 (CH2MHill, Inc. and Ecology and Environment, Inc., 1984, p. 2:3).

\section{Well Descriptions}

Information on well construction and the location of wells in the study area was compiled (table 1 and figs. 2, 3) to ascertain what data were available and which wells would provide the most information when the geophysical logging and aquifer testing were conducted. This information was provided by USEPA (Douglas Yeskis, U.S. Environmental Protection Agency, written commun., 1986). 
Table 1.--observation well data from the study area

[ft, feet; TOC, top of outer casing; <, less than; -- Indicates data unavallable]

\begin{tabular}{|c|c|c|c|c|c|c|c|c|}
\hline $\begin{array}{l}\text { Well } \\
\text { name }\end{array}$ & $\begin{array}{l}\text { Open } \\
\text { to: } 1\end{array}$ & $\begin{array}{l}\text { Depth } \\
\text { of } \\
\text { well } \\
(f t)\end{array}$ & $\begin{array}{c}\text { Depth } \\
\text { to } \\
\text { water } \\
5 / 18 / 87 \\
\text { (ft) }\end{array}$ & $\begin{array}{l}\text { Open } \\
\text { interval } \\
\text { (feet } \\
\text { below } \\
\text { TOC) }\end{array}$ & $\begin{array}{l}\text { Casing } \\
\text { dlameter } \\
\text { (1nches) }\end{array}$ & $\begin{array}{l}\text { Measuring } \\
\text { polnt } \\
\text { altitude } \\
(f t)\end{array}$ & $\begin{array}{c}\text { Water } \\
\text { level } \\
\text { altitude } \\
5 / 18 / 87 \\
(f t)\end{array}$ & $\begin{array}{l}\text { Casing } \\
\text { type }\end{array}$ \\
\hline DPW & SS & 310 & 152.7 & $190-310$ & 6 & 837 & 684.3 & Iron \\
\hline SPW & GP & 150 & 84.5 & $20-150$ & 6 & 835 & 751.5 & Iron \\
\hline $\begin{array}{l}B-1 \\
B-2\end{array}$ & $\begin{array}{l}\text { GPWT } \\
\text { GPWT }\end{array}$ & $\begin{array}{l}36 \\
59\end{array}$ & -- & $\begin{array}{l}22-36 \\
40-59\end{array}$ & $\begin{array}{l}2 \\
2\end{array}$ & $\begin{array}{l}768 \\
793\end{array}$ & $\begin{array}{l}<732 \\
<734\end{array}$ & $\begin{array}{l}\text { PVC } \\
\text { PVC }\end{array}$ \\
\hline$B-3$ & GPWT & 50 & 48.9 & $36-50$ & 2 & 823 & 774.1 & PVC \\
\hline $\begin{array}{l}B-4 \\
B-5\end{array}$ & $\begin{array}{l}\text { GPWT } \\
\text { GPWT }\end{array}$ & $\begin{array}{l}90 \\
41\end{array}$ & $\begin{array}{l}81.7 \\
40.0\end{array}$ & $\begin{array}{l}67-90 \\
25-31\end{array}$ & $\begin{array}{l}2 \\
2\end{array}$ & $\begin{array}{l}835 \\
846\end{array}$ & $\begin{array}{l}753.3 \\
806.0\end{array}$ & $\begin{array}{l}\text { PVC } \\
\text { PVC }\end{array}$ \\
\hline$B-6$ & GPWT & 95 & -- & $80-94$ & 2 & 850 & $<756$ & ovc \\
\hline$R R-1$ & $\mathrm{QA}$ & 57 & 8.2 & $40-55$ & 2 & 680 & 671.8 & SST \\
\hline RR-2 & QAWT & 27 & 7.8 & $11-27$ & 2 & 679 & 671.2 & SST \\
\hline PC-1 & GPWT & 55 & 38.0 & $?-55$ & 2 & 757 & 742.0 & PVC \\
\hline PC-2 & GPWT & 128 & 88.4 & $?-127$ & 2 & 830 & 741.6 & PVC \\
\hline$P C-3$ & GPWT & 117 & 86.8 & $8-117$ & 2 & 829 & 742.0 & PVC \\
\hline MS- 1 & TS & 47 & 36.0 & $37-47$ & 2 & 729 & 693.0 & SST \\
\hline$M S-2$ & ss & 87 & 53.6 & $72-82$ & 2 & 731 & 677.4 & SST \\
\hline MW-8 & TS & 180 & 102.0 & $170-180$ & 2 & 853 & 751.0 & SST \\
\hline MW-9 & GPWT & 106 & 97.8 & $96-106$ & 2 & 853 & 755.2 & SST \\
\hline$M W-10$ & TSHH & 189 & 95.6 & $178-189$ & 2 & 853 & 757.4 & SST \\
\hline$M W-11$ & TS & 81 & 29.0 & $71-81$ & 2 & 748 & 719.0 & SST \\
\hline MW- 15 & GPWT & 86 & 72.0 & $75-85$ & 2 & 823 & 751.0 & SST \\
\hline$M W-16$ & GP & 122 & 72.9 & $112-122$ & 2 & 824 & 751.1 & SST \\
\hline$M W-18$ & SS & 237 & 153.3 & $227-237$ & 2 & 853 & 699.7 & SST \\
\hline$M W-20$ & sS & 184 & 101.3 & $173-183$ & 2 & 823 & 721.7 & SST \\
\hline $\mathrm{MW}-30$ & GPWT & 41 & 40.2 & $27-41$ & 2 & 759 & 718.8 & SST \\
\hline$M W-31$ & GPWT & 67 & 55.1 & $54-67$ & 2 & 774 & 718.9 & SST \\
\hline$P W-3$ & GPWT & 91 & 81.2 & $10-91$ & 6 & 832 & 750.8 & Iron \\
\hline$G W-16$ & GPSS & 133 & 55.7 & $16-133$ & 6 & 789 & 733.3 & Iron \\
\hline$G W-42$ & GPWT & 101 & 81.3 & $5-101$ & 6 & 833 & 751.7 & Iron \\
\hline $\mathrm{PZ}-1$ & GPWT & 115 & 86.2 & $20-115$ & 6 & 839 & 752.8 & Iron \\
\hline $\mathrm{PZ}-2$ & GPWT & 115 & 65.3 & $20-115$ & 6 & 829 & 763.7 & Iron \\
\hline G- 16 & SS & 237 & 148.7 & $3-237$ & $<1$ & 833 & 684.3 & PVC \\
\hline$G W-44$ & GPSS & 230 & obstructed & -- & -- & -- & -- & -- \\
\hline
\end{tabular}

${ }^{1}$ Ss, St. Peter aquifer; GR, Galena-Plattev1lle aquifer; GPWT, water table, Galena-Platteville aquifer; $Q A$, Alluvial aquifer in Quaternary deposits; QAWT, Water table, alluvial aquifer in Quaternary deposits; TS, Galena-Platteville aquifer at the top of the Harmony Hill Shale Member of the Glenwood Formation; TSHH, Top of and in the Harmony Hill Shale Member of the Glenwood Formation; GPSS, GalenaPlatteville and St. Peter aquifer.

2PVC, polyvinylchloride; SST, stalnless steel. 


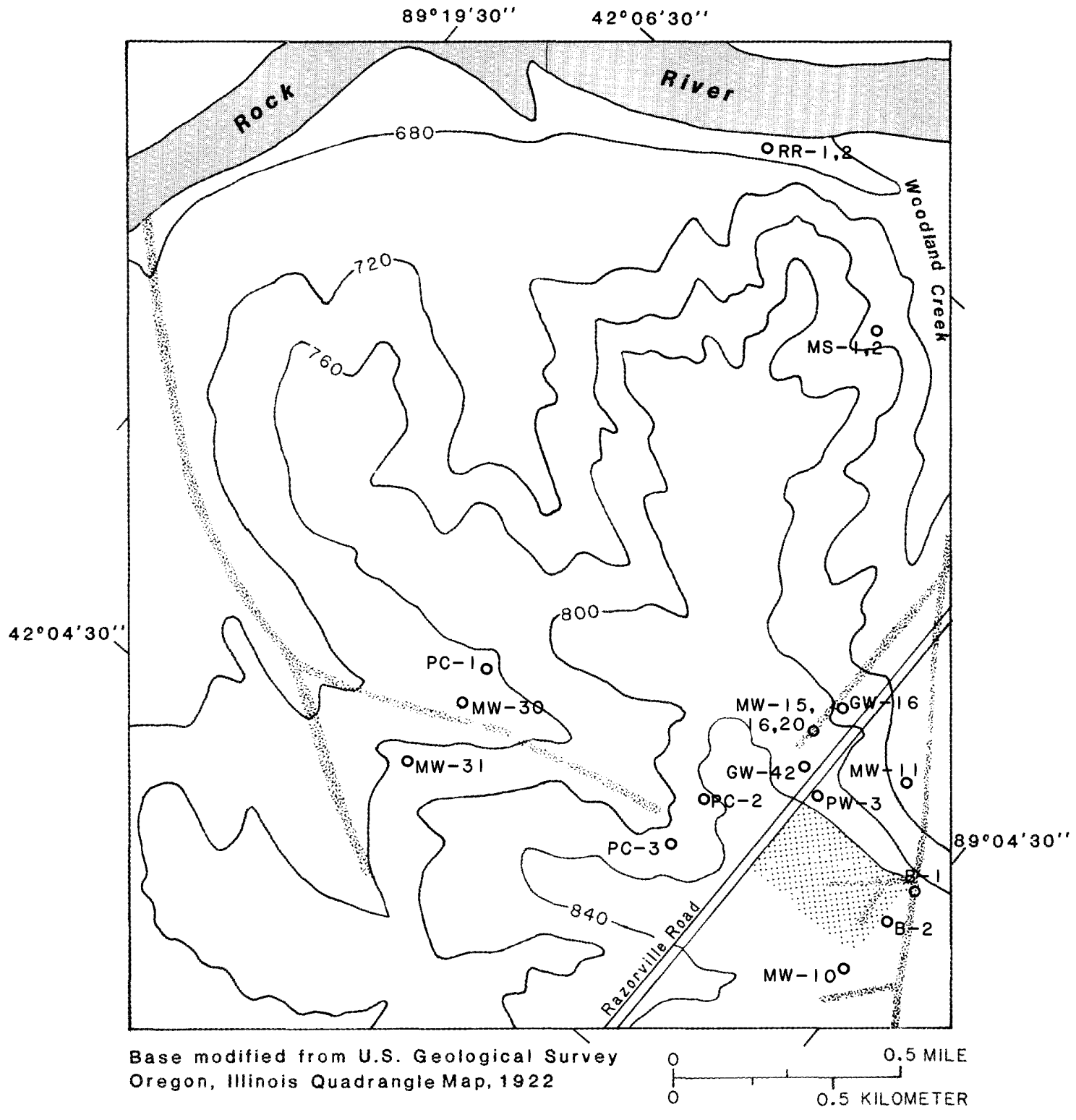

EXPLANATION

-800- TOPOGRAPHIC CONTOUR. Shows elevation of land surface, in feet. Contour interval 40 feet. Datum is sea level.

Fas FRACTURE TRACE

SALVAGE YARD

OPC-2 WELL LOCATION AND NAME

Figure 2.--Location of observation wells in the study area. 


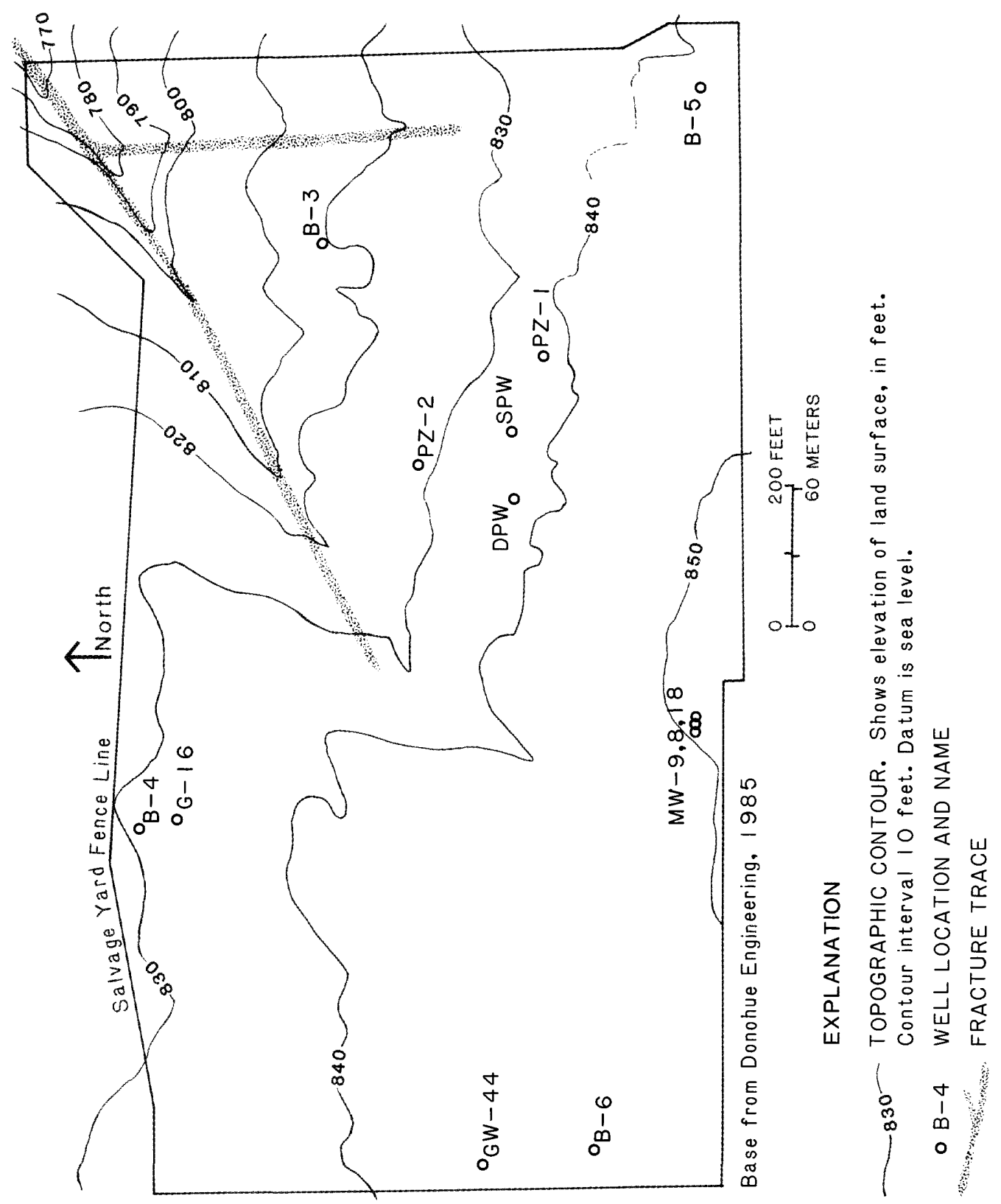

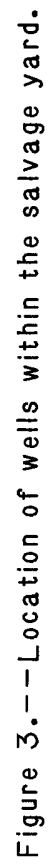


The majority of the wells in the study area can be divided into three hydrogeologic categories. Most of the wells in the study area are open to the water table in the Galena-Platteville aquifer or the alluvial aquifer in Quaternary deposits. Two wells are open to the base of the Galena-Platteville aquifer at the top of the Harmony Hill Shale Member of the Glenwood Formation. Several wells are open to the st. Peter aquifer.

A number of wells do not fit neatly into any of the above categories. Some wells are open to the middle or all of the Galena-Platteville aquifer and two of these also penetrate the st. Peter aquifer. One well, the integrity of which is suspect (Kenneth Wallace, U.S. Environmental Protection Agency, oral commun., 1987), is open to the Harmony Hill Shale Member and the GalenaPlatteville aquifer above the shale. One well is open to the alluvial aquifer in Quaternary deposits approximately $30 \mathrm{ft}$ below the water table.

\section{Acknowledgments}

The authors wish to extend their appreciation to Kenneth wallace, former Project Manager, and Douglas Yeskis, Geologist, of the U.S. Environmental Protection Agency, for their support and active participation during this project. The authors also appreciate the assistance of suzanne Hartnett, formerly of Camp, Dresser and McKee, Inc., in obtaining the rock core used for laboratory-determined porosity values. Paul Karmazinski, Nus Corporation, and Stephen J. Terhar, Northern Illinois University, are thanked for their assistance during the aquifer tests.

\section{HYDROGEOLOGY}

The hydrogeology of the study area has been described by a number of investigators including Piskin (1976, plate 7) and Yeskis (U.S. Environmental Protection Agency, written commun., 1987). The interpretations presented in this report are similar to those of previous authors but are based on data from additional wells that they did not have access to.

\section{General Geology}

The geology in the study area has been described by a number of authors including Piskin (1976, p. 14-19) and Gilkeson and others (1977, p. 19-24). The stratigraphic nomenclature used in this report is that of the Illinois State Geological Survey (ISGS) (WIllman and others, 1975, p. 61-80 and 218-230) and does not necessarily follow the usage of the U.S. Geological survey.

The work of Piskin (1976, p. 14-19), combined with the lithologic descriptions of a 2-inch diameter core from well MW-20, drill cuttings from well DPW, and analysis of the geophysical logs (appendix 1) (fig. 4), provide the basis for the discussion of the geology in the study area. The geology consists, from oldest to youngest, of ordovician sandstone, shale, and dolomite in the St. Peter Sandstone and Glenwood Formations and the Platteville and Galena Groups, that are unconformably overlain by quaternary glacial, fluvioglacial, and alluvial deposits (fig. 5). 


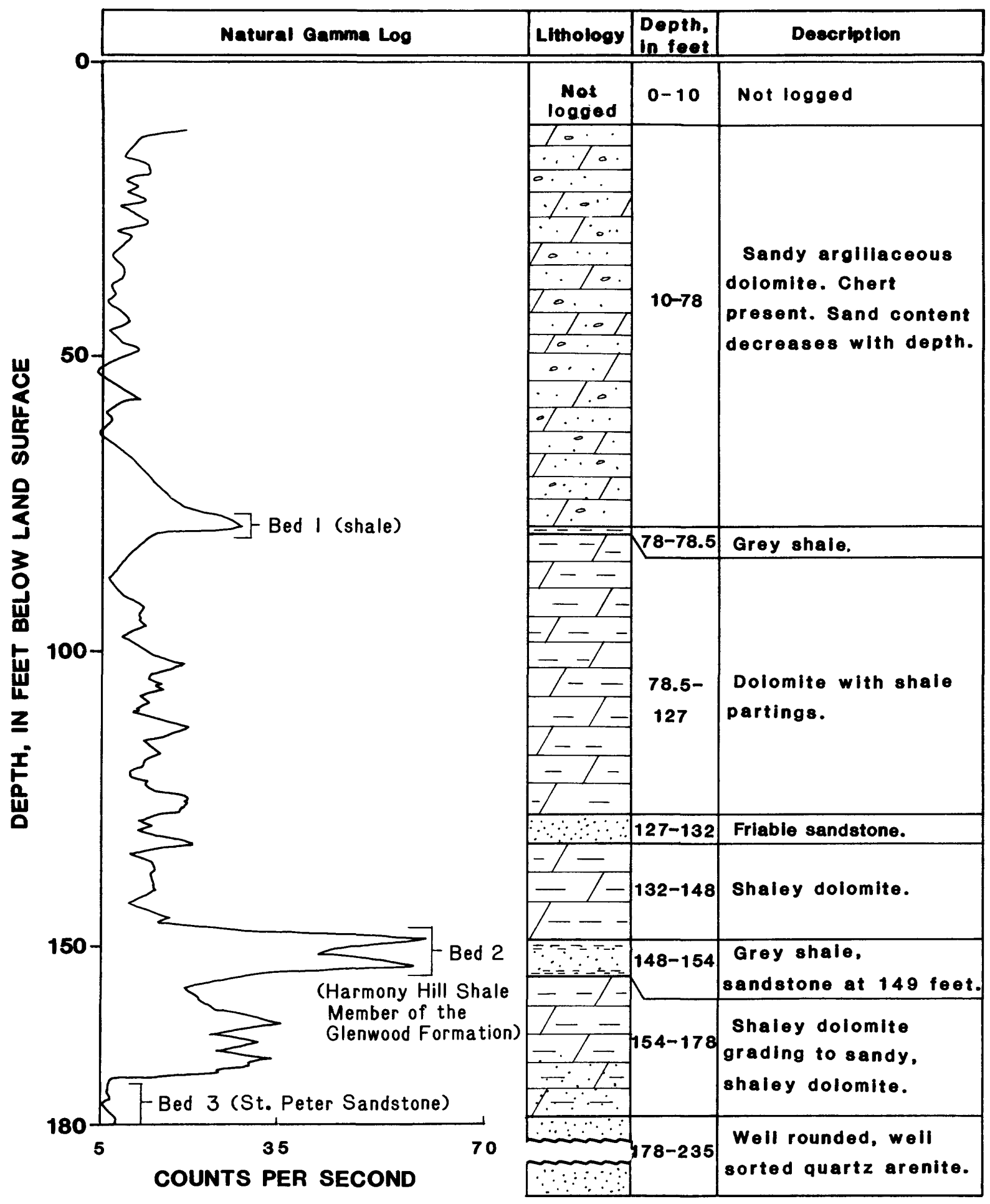

Figure 4.-- Natural gamma-log, lithologic $\log$, and generalized stratigraphic section for well $M W-20$. 


\begin{tabular}{|c|c|c|c|c|c|c|c|c|c|}
\hline$\underset{\omega}{\stackrel{E}{0}}$ & $\begin{array}{l}\frac{0}{2} \\
\frac{0}{0}\end{array}$ & 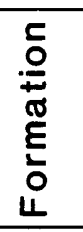 & 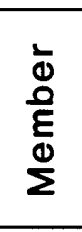 & \multicolumn{3}{|c|}{ Lithology } & \multicolumn{3}{|c|}{$\begin{array}{c}\text { Thickness, } \\
\text { in feet }\end{array}$} \\
\hline \multirow{5}{*}{ 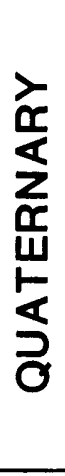 } & & & & \multicolumn{3}{|c|}{$\begin{array}{l}\text { Alluvium, silty at top, grading downward } \\
\text { to sand with occasional gravel }\end{array}$} & \multicolumn{3}{|c|}{$0-20$} \\
\hline & & & & $\begin{array}{l}\text { Loess, } \\
\text { windblown silt, } \\
\text { leached }\end{array}$ & $\begin{array}{l}\text { Sand and silt, } \\
\text { windblown, } \\
\text { leached }\end{array}$ & $\begin{array}{l}\text { Outwash, sand } \\
\text { and gravel }\end{array}$ & $\begin{array}{c}0 \\
1 \\
1 \\
0\end{array}$ & $\frac{1}{1}$ & $\begin{array}{l}0 \\
0 \\
1 \\
\vdots \\
0\end{array}$ \\
\hline & & & & \multicolumn{3}{|c|}{$\begin{array}{l}\text { Till, brown silty clay to clayey silt with few } \\
\text { boulders, stiff }\end{array}$} & \multicolumn{3}{|c|}{$0-26$} \\
\hline & & & & \multicolumn{3}{|c|}{ Silt, brown to gray, calcareous, stiff } & \multicolumn{3}{|c|}{$0-10$} \\
\hline & & & & \multicolumn{3}{|c|}{$\begin{array}{l}\text { Till, brown silty sand with few boulders, very stiff } \\
\text { to hard }\end{array}$} & \multicolumn{3}{|c|}{$0-25$} \\
\hline \multirow{10}{*}{$\begin{array}{l}\frac{z}{4} \\
\frac{0}{0} \\
\frac{8}{0} \\
0 \\
\frac{0}{0}\end{array}$} & \multirow{2}{*}{$\frac{\sum_{1}^{\frac{1}{2}}}{\mathrm{~d}}$} & 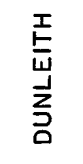 & & \multicolumn{3}{|c|}{$\begin{array}{l}\text { Dolomite, buff, finely crystalline, thin } \\
\text { to medium bedded with white and gray chert } \\
\text { nodules, green shale partings in lower portion }\end{array}$} & \multicolumn{3}{|c|}{$0-100$} \\
\hline & & 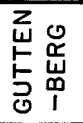 & & \multicolumn{3}{|c|}{$\begin{array}{l}\text { Dolomite, buff, red speckled with red shale } \\
\text { partings }\end{array}$} & \multicolumn{3}{|c|}{$0-6$} \\
\hline & & $\sum_{\substack{2 \\
\bar{z}}}^{\infty}$ & & \multicolumn{3}{|c|}{$\begin{array}{l}\text { Dolomite, buff and gray, occasional white chert } \\
\text { nodules }\end{array}$} & \multicolumn{3}{|c|}{$0-13$} \\
\hline & ш & 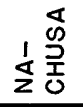 & & \multicolumn{3}{|c|}{$\begin{array}{l}\text { Dolomite, buff or gray, occasional white chert } \\
\text { nodules }\end{array}$} & \multicolumn{3}{|c|}{$0-23$} \\
\hline & $\stackrel{\rightleftarrows}{\rightleftarrows}$ & $\begin{array}{l}\sum_{0}^{\frac{x}{2}} \\
\text { 采 } \\
\text { 岀 }\end{array}$ & & \multicolumn{3}{|c|}{$\begin{array}{l}\text { Dolomite, mottled buff and dark gray, finely } \\
\text { crystalline, medium to massive bedded, thin gray } \\
\text { and reddish-brown shale partings }\end{array}$} & \multicolumn{3}{|c|}{$0-46$} \\
\hline & $\frac{\overleftarrow{a}}{\alpha}$ & $\begin{array}{l}\underset{J}{J} \\
\frac{U}{\Sigma} \\
\Sigma\end{array}$ & & \multicolumn{3}{|c|}{$\begin{array}{l}\text { Dolomite, buff to gray, finely crystalline, medium to } \\
\text { massive bedded, thin gray or green shale partings }\end{array}$} & \multicolumn{3}{|c|}{$0-26$} \\
\hline & & 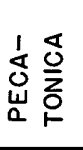 & & \multicolumn{3}{|c|}{$\begin{array}{l}\text { Dolomite, mottled white and dark gray, occasional } \\
\text { finely crystalline, medium to massive bedded, thin } \\
\text { gray shale partings }\end{array}$} & \multicolumn{3}{|c|}{$0-31$} \\
\hline & & ஜి & 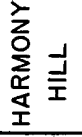 & \multicolumn{3}{|c|}{ Shale, green, gray, and brown, thinly laminated } & \multicolumn{3}{|c|}{$0-5$} \\
\hline & & $\sum_{u}^{3}$ & 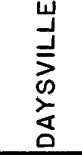 & \multicolumn{3}{|c|}{$\begin{array}{l}\text { Shale, brown and gray, sandy } \\
\text { Dolomite, greenish-gray, fine-grained } \\
\text { Dolomitic sandstone, greenish-gray }\end{array}$} & \multicolumn{3}{|c|}{$0-32$} \\
\hline & & 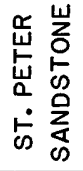 & & \multicolumn{3}{|c|}{ Sandstone, white, fine-grained, quartzose, friable } & \multicolumn{3}{|c|}{$\begin{array}{c}\text { approximately } \\
420\end{array}$} \\
\hline
\end{tabular}

(Modified from Gilkeson and others, 1977)

Figure 5.--Stratigraphy of the Ordovician rocks and Quaternary deposits in the study area. 
The St. Peter sandstone is a fine- to coarse-grained quartz arenite, characterized by a high percentage of well-rounded quartz grains. There are no wells that penetrate the entire thickness of the st. Peter aquifer in the study area; however, well logs obtained from the Illinois state water survey for two wells at the Byron Station Power Plant (fig. 1) indicate that the St. Peter aquifer is approximately $420 \mathrm{ft}$ (feet) thick in this area.

The Glenwood Formation is a highly heterogeneous unit of sandstone, dolomite, and shale that overlies the st. Peter sandstone. The base of the Glenwood Formation consists of argillaceous dolomite that grades downward into a dolomitic sandstone. The uppermost unit of the Glenwood Formation is the Harmony Hill Shale Member which is a grey-green shale from 1.5 to $5.0 \mathrm{ft}$ thick in the study area.

The Platteville Group consists of crystalline, partly argillaceous dolomite. The upper part of the Platteville Group commonly contains chert. Shale partings are common throughout the Platteville Group. The thickness of the Platteville Group ranges from 0 to $140 \mathrm{ft}$ in the study area.

The Galena Group consists of partly cherty, partly argillaceous dolomite with shale partings present throughout the deposits. The thickness of the Galena Group ranges from 0 to $106 \mathrm{ft}$ in the study area.

Quaternary deposits, generally less than $30 \mathrm{ft}$ thick in the study area and less than $10 \mathrm{ft}$ thick at the salvage yard, lie unconformably on the bedrock. These unconsolidated surficial deposits consist of till, loess, eolian sand and silt; and fluvioglacial and alluvial sands, and sandy gravels. Alluvial deposits are located in the valley of the Rock River, the lower reaches of Woodland creek, and other tributaries of the Rock River. The thickness of alluvial material is variable, increasing downstream along creeks toward the Rock River. wind-blown deposits (loess) and two underlying till units comprise the surficial deposits in the upland and interstream areas.

The topography of the study area and location of a line of geologic section $C-C^{\prime}$ are presented in figure 6 . Figure 7 shows geologic section C-C', which was constructed from lithologic logs for wells RR-1, MS-2, MW-20, and MW-18. As can be seen from figure 7, the bedrock consists of dolomites in the Galena and Platteville Groups throughout most of the study area. Near the Rock River, the Galena and Platteville Groups and Glenwood Formation have been removed by erosion, and the bedrock is the st. Peter sandstone.

In a study of the faulting in and around the study area conducted by Sargent and Lundy, Inc., and Dames and Moore, Inc. (1975, p. 7-33), several important conclusions concerning the nature and origin of the vertical faults were made. The report noted that the main fault in the study area has a displacement of $6 \mathrm{in.} \mathrm{(inches)} \mathrm{and} \mathrm{probably} \mathrm{influenced} \mathrm{the} \mathrm{development} \mathrm{of} \mathrm{the}$ topographic low associated with woodland creek (fig. 1). The report also noted that there are two main directions of strike to the faults and joints in the Byron area: $\mathrm{N} .60^{\circ} \mathrm{W}$. to $\mathrm{N} .75^{\circ} \mathrm{W}$. and $\mathrm{N} .15^{\circ} \mathrm{E}$. to $\mathrm{N} .30^{\circ} \mathrm{E}$. The trend from $\mathrm{N} .60^{\circ} \mathrm{W}$. to $\mathrm{N} .75^{\circ} \mathrm{W}$. is the dominant structural trend in the area. Clays have at least partly infilled some of the faults and joints in the study area. 


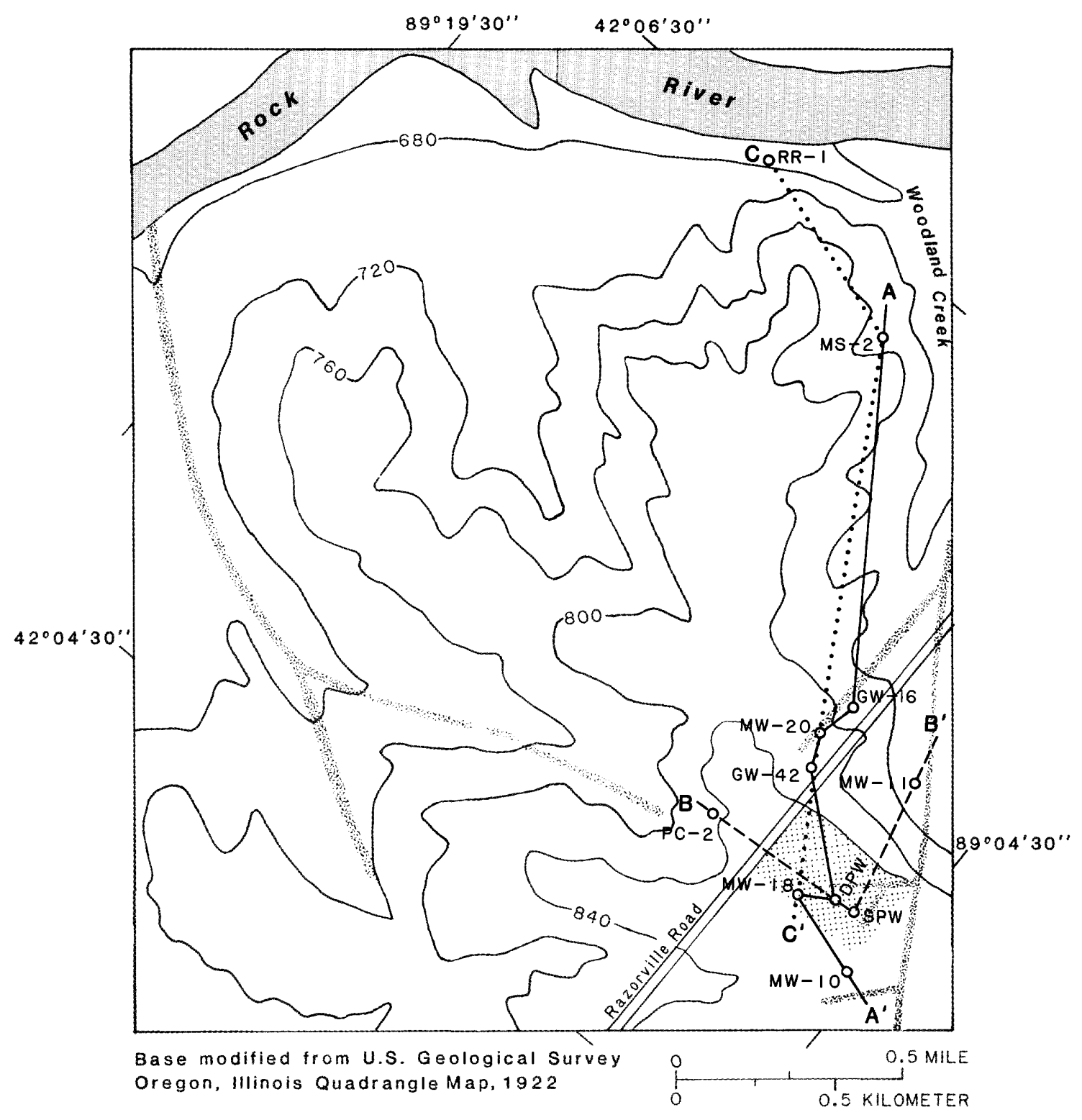

EXPLANATION

-800- TOPOGRAPHIC CONTOUR. Shows elevation of land surface, in feet. Contour interval 40 feet. Datum is sea level.

WX

SALVAGE YARD

OPC-2 WELL LOCATION AND NAME

$A \longrightarrow A^{\prime}$ LINE OF SECTION

B----B' LINE OF SECTION

C....... C' LINE OF SECTION. GW-42 not included.

Figure 6.--Location of lines of section in the study area. 


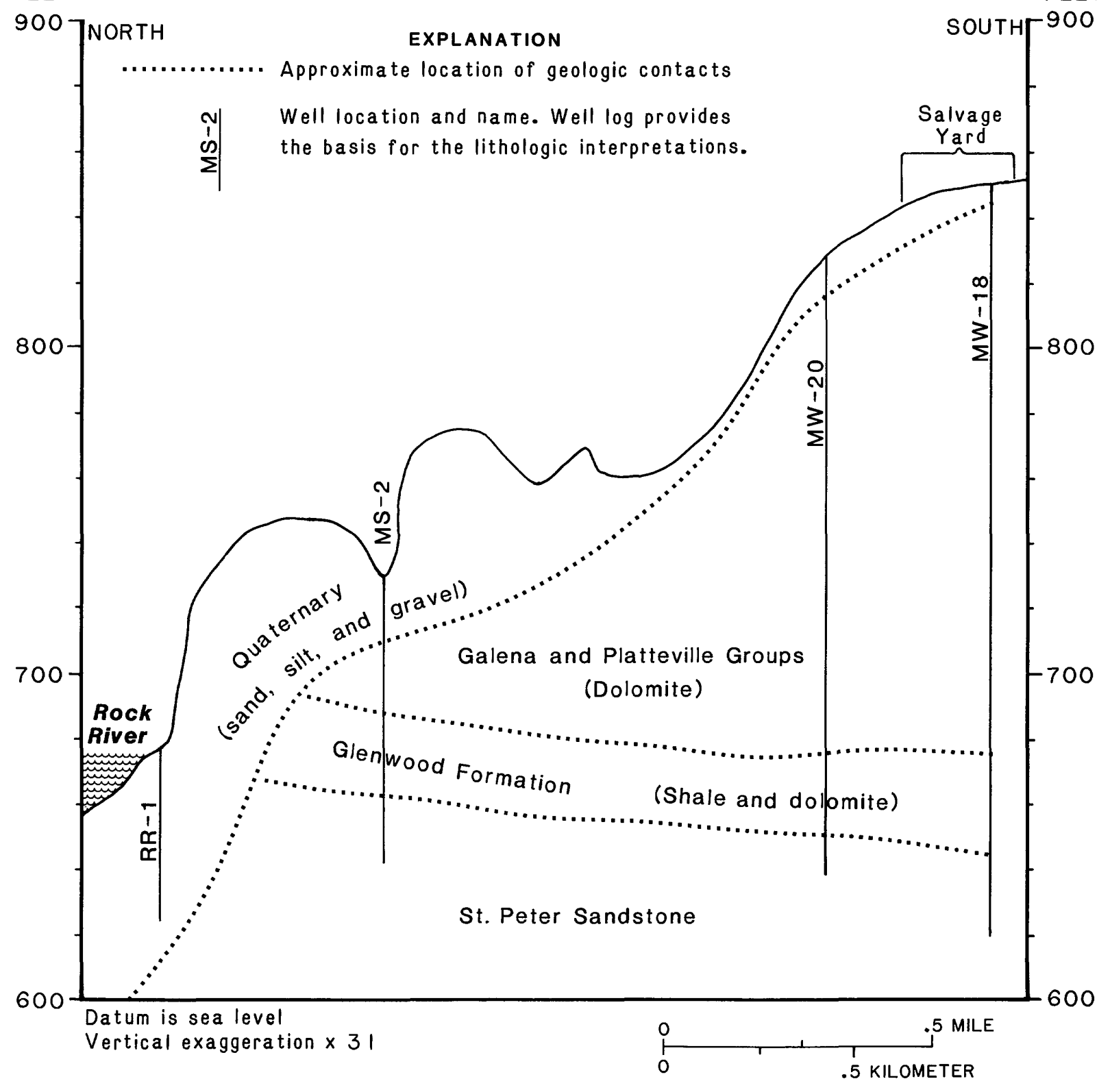

Figure 7. - Geologic section $C-C^{\prime}$. 
The report concluded that the faulting in the area is related to movement a long the Sandwich Fault zone, a part of which is $7 \mathrm{mi}$ south of the study area. Development of the sandwich Fault zone occurred after deposition of the youngest bedrock in northern Illinois (Ordovician and silurian age) but prior to deposition of the Pleistocene deposits.

\section{Hydrology}

From October 1985 through December 1987, water levels were collected at most of the wells in the study area on a regular basis by the USEPA (Douglas Yeskis, U.S. Environmental Protection Agency, written commun., 1987). During that period, no more than 3 months elapsed between measurements so that seasonal fluctuations in water level could be monitored. These data have provided a great deal of insight into the nature of the hydrology in the Byron area.

Considered on a regional basis, the hydrology of the study area is fairly simple. The Platteville and Galena Groups are lithologically and hydrologically similar and are treated as a single hydrogeologic unit, the GalenaPlatteville aquifer. The Galena-Platteville is an unconfined, water-table aquifer in the study area. The Harmony Hill Shale Member of the Glenwood Formation is a semiconfining unit between the underlying st. Peter aquifer and the overlying Galena-Platteville aquifer. The St. Peter aquifer is a confined artesian aquifer in the study area except in the vicinity of the Rock River, where Quaternary alluvial deposits comprise an unconfined aquifer.

The direction of ground-water flow in both the Galena-Platteville and St. Peter aquifers is toward the Rock River. The ground-water flow system changes from recharging to discharging along the flow path in the study area. In the upland areas near the site, ground water is recharged from the water table to the base of the Galena-Platteville aquifer then to the st. Peter aquifer. Ground water discharges to the Rock River at the edge of the study area.

\section{Alluvial Aquifer}

The hydrology of the alluvial aquifer is not well understood because of the scarcity of observation wells in this aquifer. The water-level data that are available from wells $R R-1$ and RR-2 demonstrate that the head $30 \mathrm{ft}$ below the water table in the alluvial aquifer is approximately $0.04 \mathrm{ft}$ higher than the head at the water table in the vicinity of the Rock River (table 1), indicating discharge of ground water into the river.

\section{Galena-Platteville Aquifer}

Water-level measurements made from January 1986 to January 1987 were used to construct a map of the average water-table altitude in the study area (fig. 8). In the area of the salvage yard, the water table is located in the Galena-Platteville aquifer. North and west of the salvage yard, the dolomites have been eroded away ( $\mathrm{fig}$. 7) so that the water-table altitude is determined by water levels in the alluvial aquifer in the vicinity of the Rock River. 


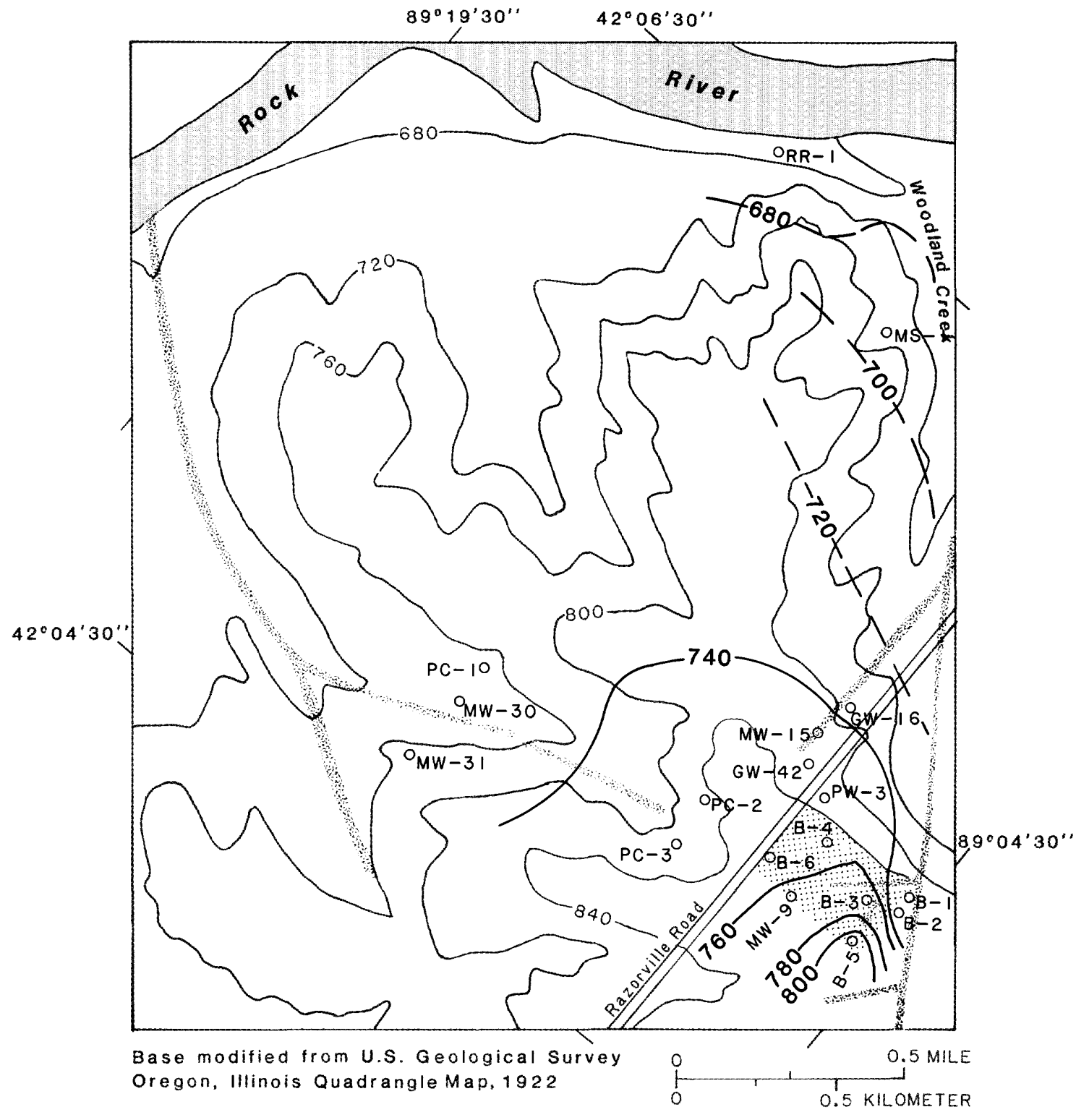

\section{EXPLANATION}

-800- TOPOGRAPHIC CONTOUR. Shows elevation of land surface, in feet. Contour interval 40 feet. Datum is sea level.

mistom FRACTURE TRACE

SALVAGE YARD

OPW-3 WELL LOCATION AND NAME

$740-$ WATER-TABLE CONTOUR. Shows average altitude of the water inferred. Contour interval 20 feet. Datum is sea level.

Figure 8.--Average water-table altitude during the 1986 calendar year. 
The overall direction of ground-water flow in the study area is toward the Rock River. The water table is at its highest altitude near the southeastern corner of the salvage yard and at its lowest altitude at the Rock River. The altitude and configuration of the water table generally are a subdued reflection of topography over the study area. Extrapolation of the water table away from the salvage yard is highly speculative because of the sparsity of data for this area.

In the upland areas at and near the salvage yard, the head at the water table is approximately 1 to $5 \mathrm{ft}$ higher than the head at the base of the Galena-Platteville aquifer (compare water-level altitudes at wells MW-8 and MW-9 in table 1). This indicates a potential for recharge from the water table to the bottom of the aquifer in this area.

Water-level measurements collected on May 18-19, 1987, were used to construct a map of the water-table altitude and configuration beneath the salvage yard (fig. 9). The water-table map indicates the presence of a ground-water divide that trends approximately southeast-northwest through the salvage yard. Northeast of the divide, flow is toward the topographic low at Woodland Creek. Southwest of the divide, flow is toward the topographic low associated with the fractures west of the salvage yard. Wells B-1, B-2, and B-6 were dry when measured in May 1987 and are used only to establish an upper limit to the water-table altitude in the area.

Open intervals in wells B-3, B-4, B-5, and MW-9 extend above and below the free water surface (table 1) and penetrate less than $10 \mathrm{ft}$ of the saturated thickness of the aquifer, indicating that water levels in these wells accurately represent the altitude of the water table. Wells PZ-1, PZ-2, and SPW are open to at least 29, 50, and $65 \mathrm{ft}$ of the saturated thickness of the aquifer, respectively. The water-level altitude in these wells is lower than the true water-table altitude due to vertical downward gradients present in the aquifer at these wells (Douglas Yeskis, U.S. Environmental Protection Agency, written commun., 1987). It is assumed that the water levels in wells PZ-1, PZ-2, and SPW accurately reflect the water-table altitudes at those locations to facilitate data analysis and to obtain the maximum number of data points.

The water-table wells in the area of the salvage yard can be divided into three groups on the basis of the water-table configuration shown in figure 9. Group I wells (PW-3, B-4, SPW, PZ-1, MW-9, B-6) define the relatively flat part of the water table underlying the western half of the yard. Group II wells (B-3, $B-5, \mathrm{PZ}-2)$ define the ground-water divide that extends southeastnorthwest across the salvage yard. Group III wells (B-1, B-2) represent low water-table conditions, present to the east of the salvage yard, that are associated with the fault at Woodland creek.

Several possible geologic and hydrologic factors might control the water table configuration beneath the salvage yard. They include the following:

1. Variable leakage rates through the Harmony Hill Shale Member of the Glenwood Formation; 


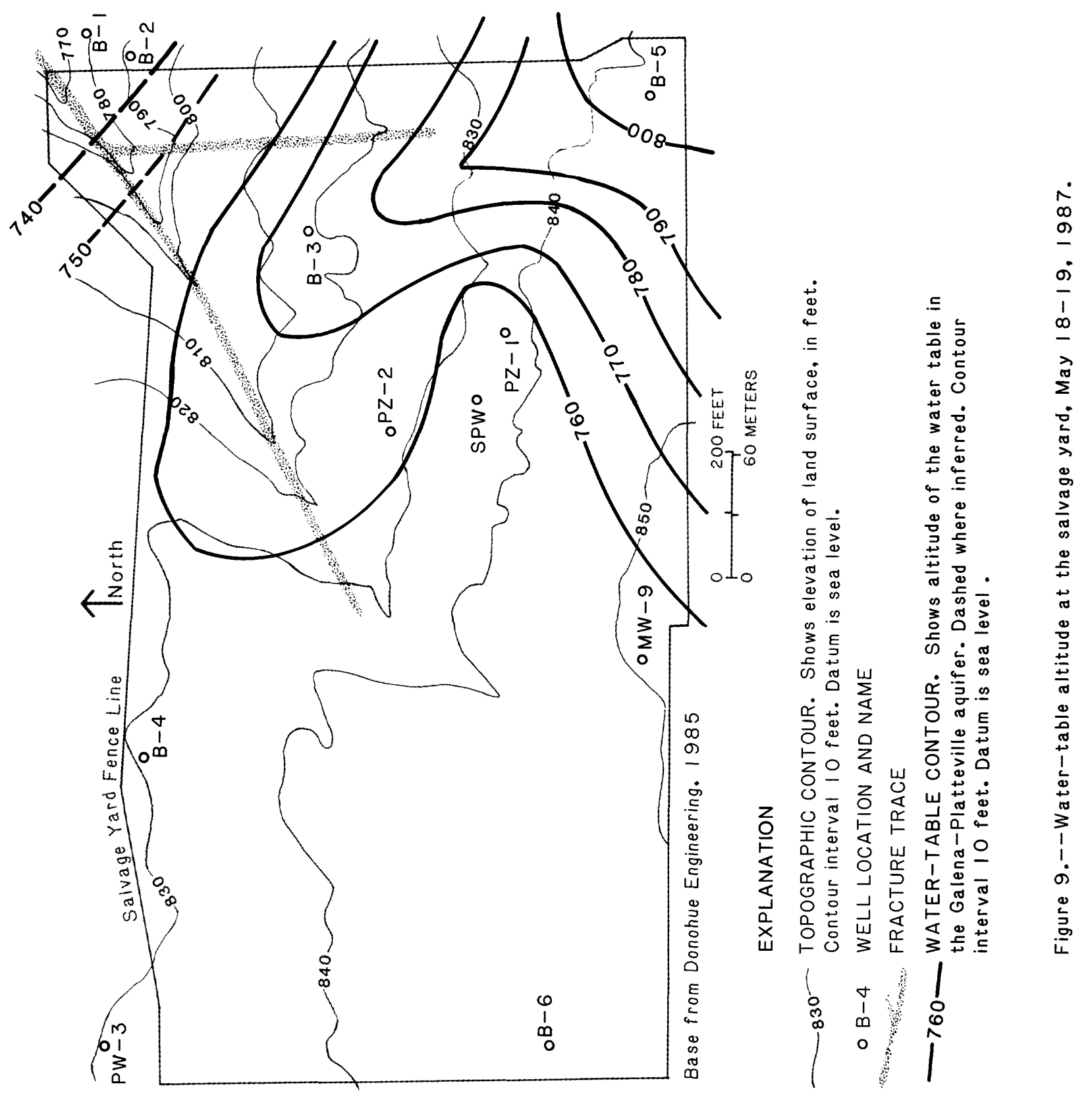


2. Topographic control, assuming that the water-table relief generally follows that of the land surface;

3. Permeability distribution, assuming that water-table altitudes increase in areas where permeability is low and water-table altitudes decrease in areas where permeability is high; and

4. Vertical low-permeability barriers along the flow path that act as a dam, causing a buildup of water upgradient from the barriers.

On the basis of interpretations of lithologic and natural-gamma logs, there is no evidence to suggest that the Harmony Hill Shale Member differs significantly in either thickness or competency across the salvage yard. It is assumed, therefore, that there is little areal variation in vertical leakage rates through the Harmony Hill.

Although ground-water-flow patterns and the water-table configuration seem to be related to topography in the study area as a whole (fig. 8), figure 9 shows that other factors control the position of the water table at the salvage yard. This can be seen when comparing water-level and measuring-point altitudes at wells B-3, B-5, MW-9, and PZ-2 (table 1). Measuring-point altitudes at wells B-3, B-5, and PZ-2 are lower than at well MW-9, whereas the water-table altitude is significantly higher in these wells than in well MW-9, indicating that factors other than topography control the water-table altitude beneath the salvage yard.

The major factors controlling the position of the water table at the salvage yard seem to be lithologic and structural controls on permeability distribution. Support for this statement can be found in the work of LeGrand and stringfield (1971, p. 5) who found that lateral variations in water-table altitude may exist locally because of lateral variations in permeability within carbonate-rock terrains.

If the water-table altitude is a function of permeability distribution, the following conclusions can be drawn:

1. The flat part of the water table represented by Group I wells indicates a region in the aquifer where a system of interconnected fractures and uniform permeability distribution is relatively well developed.

2. The water-table high defined by the Group II wells indicates a zone of low permeability and low degree of fracture interconnection within the aquifer, perhaps because of clay infilling of fractures.

3. The low water-table conditions represented by the Group III wells appear to be associated with the highly fractured, presumably transmissive zone associated with the fault near the northeastern corner of the salvage yard. This fault zone extends to the northwest toward the Rock River (fig. 1) and has been defined as a possible regional ground-water sink (Piskin, 1976, p. 51).

4. The aquifer is both heterogeneous and anisotropic. 
The second conclusion is supported by comparing the water-level changes in wells PZ-1 and PZ-2 after the wells were drilled. The water-level altitude in well PZ-1 stabilized within 1 week of drilling. In contrast, the waterlevel altitude in well PZ-2 rose continually in the month following the completion of drilling before stabilizing approximately $9 \mathrm{ft}$ above the water level measured immediately after drilling. The gradual increase in water level at well PZ-2 suggests that aquifer permeability in the vicinity of well PZ-2 is much lower than aquifer permeability in the vicinity of well PZ-1.

Vertical low-permeability zones perpendicular to the general direction of ground-water flow in the area of the Group II wells, perhaps associated with a part of the vertical fracture that runs through the center of the salvage yard (fig. 9), could impede horizontal ground-water flow and cause an increase in water-table altitude upgradient from the barrier. Although there is no direct evidence to suggest the presence of vertical zones of low permeability that may have resulted from clay infilling of these fractures, the possibility of such features existing cannot be discounted.

\section{St. Peter Aquifer}

A map of water-level altitude in the wells open to the St. Peter aquifer was constructed using water-level measurements collected on May 18-19, 1987 (fig. 10). Ground-water flow in the St. Peter aquifer is from a high point at well MW-20 eastward to the topographic low associated with the fault zone at Woodland Creek and northward to the Rock River, generally following topography. The St. Peter aquifer is an artesian aquifer at wells MW-18, DPW, G-16, MW-20, and MS-2. Extrapolation of the potentiometric surface away from the salvage yard is speculative because of the scarcity of data; most of the wells screened in the st. Peter aquifer are in or near the salvage yard.

The potentiometric head at the base of the Galena-Platteville aquifer is from 30 to $50 \mathrm{ft}$ higher than the head in the underlying St. Peter aquifer beneath the salvage yard (compare water-level altitudes at wells MW-8 and MW-18 in table 1), indicating a potential for flow into the st. Peter aquifer from the Galena-Platteville aquifer. Away from the salvage yard, at wells MS-1 and MS-2, head at the base of the Galena-Platteville aquifer is approximately $16 \mathrm{ft}$ higher than it is in the underlying st. Peter aquifer, indicating that there is a smaller potential for recharge in this area.

It should be noted that data collected at additional wells drilled into the St. Peter aquifer by USEPA since the completion of this study cast some doubt as to the accuracy of the data collected at well MW-20. Although it is possible that the relatively high water-level altitude in well MW-20 is caused by an unusually high rate of leakage from the Galena-Platteville aquifer into the st. Peter aquifer through the vertical fracture present in this area (fig. 10), it also is possible that the integrity of this well may have been ruined and that the water levels there are not representative of the St. Peter aquifer. 


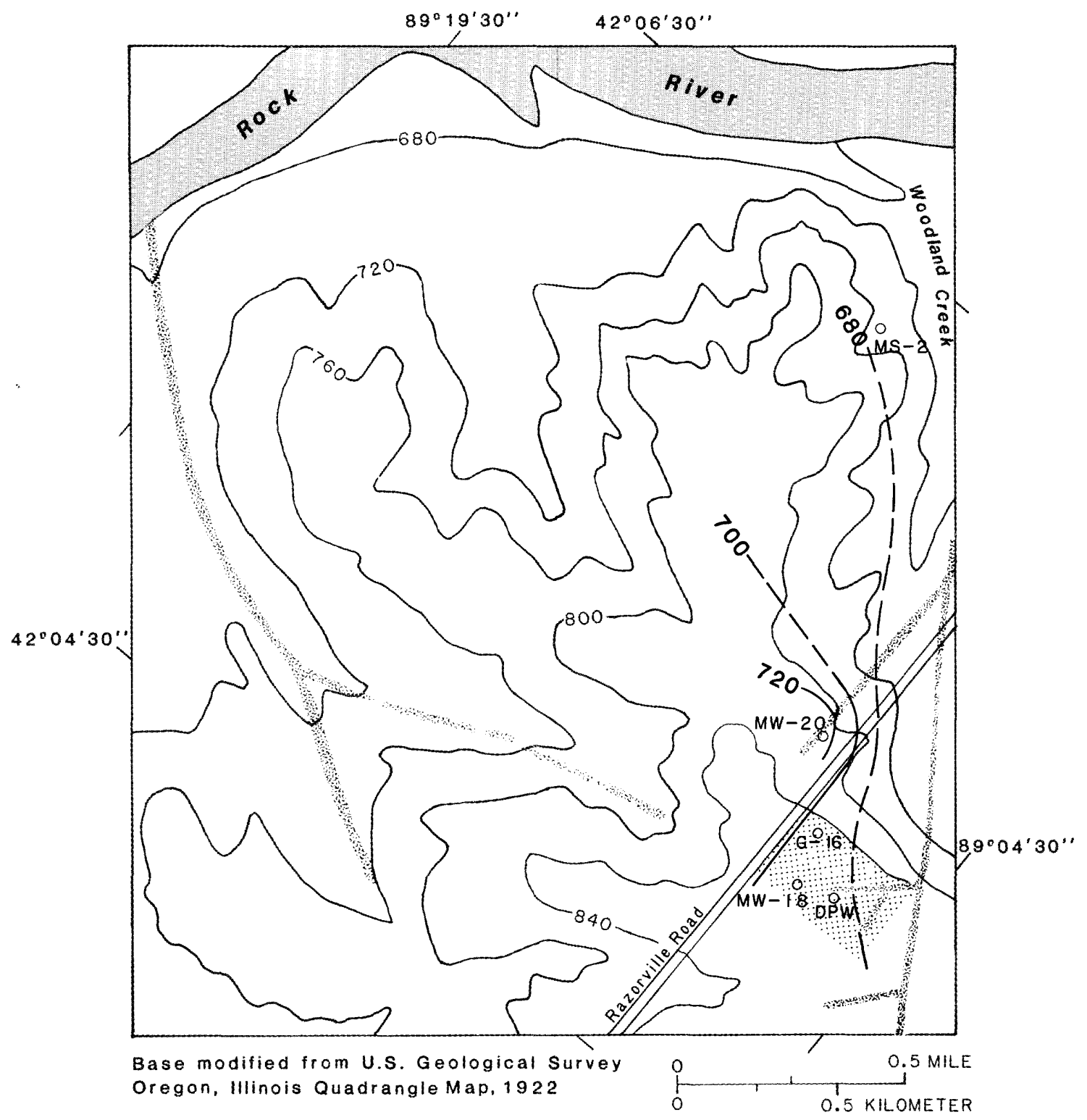

EXPLANATION

-800 TOPOGRAPHIC CONTOUR. Shows elevation of land surface, in feet. Contour interval 40 feet. Datum is sea level.

W

SALVAGE YARD

OMW-18 WELL LOCATION AND NAME

-700-WATER-LEVEL CONTOUR. Shows altitude of water levels in wells open to the $S t$. Peter aquifer. Dashed where inferred. Contour interval 20 feet. Datum is sea level.

Figure 10.--Water-level altitude in wells open to the $S t$. Peter aquifer, May $18-19,1987$. 
RESULTS OF AQUIFER TESTS

In an attempt to quantify the hydraulic properties of the aquifers, two types of aquifer tests were conducted: step-drawdown tests and constantdischarge tests.

\section{Step-Drawdown Tests}

Step-drawdown tests were conducted in the Galena-Platteville and St. Peter aquifers to determine the optimum pumping rate for each aquifer. The stepdrawdown tests provided the preliminary estimates of well yield that were used to plan the pumping rate and duration of the two constant-discharge aquifer tests.

The Galena-platteville aquifer step-drawdown test consisted of pumping well SPW at 5, 10, 15, and $20 \mathrm{gal} / \mathrm{min}$ (gallons per minute) for 100 minutes at each rate (table 2 ). The step-drawdown data obtained from well sPw indicated that the well would be capable of supporting a discharge rate of $20 \mathrm{gal} / \mathrm{min}$ for 72 hours.

The St. Peter aquifer step-drawdown test consisted of pumping well DPW at $5 \mathrm{gal} / \mathrm{min}$ for $60 \mathrm{minutes,} 10 \mathrm{gal} / \mathrm{min}$ for $100 \mathrm{minutes}$, and $20 \mathrm{gal} / \mathrm{min}$ for 100 minutes (table 3 ). The $5 \mathrm{gal} / \mathrm{min}$ step only lasted 60 minutes because drawdown in the well had ceased prior to this time. The step-drawdown data from well DPW indicated that the well would be capable of supporting a discharge rate of $20 \mathrm{gal} / \mathrm{min}$ for 48 hours without inducing water-table conditions in the

st. Peter aquifer.

\section{Constant-Discharge Tests}

Constant-discharge aquifer tests were conducted in May and June 1987. Constant-discharge aquifer tests provided the information needed to quantify the transmissivity, storage coefficient, and horizontal hydraulic conductivity of both aquifers as well as the rate of leakage through the Harmony Hill shale Member beneath the salvage yard.

Aquifer test drawdown data can be influenced by a number of factors including instrument error, barometric pressure changes, variations in the pumping rate, and background fluctuations in water level due to factors other than the pumping. A number of steps were taken to minimize the uncertainty concerning the accuracy of the drawdown data.

Water levels were monitored using pressure transducers rated at 0 to 5 and 0 to 15 pounds per square inch in all wells in which it was feasible to do so. Manually controlled input voltage regulators were used as part of the system. The transducers were capable of detecting a change in water level of less than $0.01 \mathrm{ft}$. Water levels were recorded manually and on cassette tape to guard against data loss or damage. Occasionally, water levels were measured manually to insure the accuracy of the pressure transducers. Technical problems necessitated that water-level readings in wells B-3 and G-16 be collected with electric tape. 
Table 2.--Time $(t)$, in minutes, and corresponding drawdown $(s)$, in feet, for varied discharge rates, in gallons per minute, in well SPW during the Galena-Platteville step-drawdown test of March 19, 1987

\begin{tabular}{|c|c|c|c|c|c|c|c|}
\hline \multicolumn{8}{|c|}{ Discharge rate } \\
\hline \multicolumn{2}{|c|}{5} & \multicolumn{2}{|c|}{10} & \multicolumn{2}{|c|}{15} & \multicolumn{2}{|c|}{20} \\
\hline$t$ & $\mathbf{s}$ & $t$ & $\mathbf{s}$ & $t$ & $\mathbf{s}$ & $t$ & $\mathbf{s}$ \\
\hline 0.1 & 1.22 & 0.1 & $2 \cdot 16$ & 0.1 & 3.90 & 0.1 & 8.29 \\
\hline .2 & 1.56 & .2 & 2.34 & .2 & 4.23 & .2 & 8.40 \\
\hline .4 & 2.61 & .4 & 2.41 & .4 & 4.40 & .4 & 8.52 \\
\hline .6 & 3.11 & .6 & 2.68 & .6 & 4.84 & .6 & 8.96 \\
\hline .8 & 2.95 & .8 & 2.70 & .8 & 5.01 & .8 & 9.79 \\
\hline 1.0 & 2.39 & 1.0 & 2.73 & 1.0 & 5.46 & 1.0 & 10.52 \\
\hline 2.0 & 2.11 & 2.0 & 3.23 & 2.0 & 5.62 & 2.0 & 14.48 \\
\hline 3.0 & 2.00 & 3.0 & 3.45 & 3.0 & 5.79 & 3.0 & 18.52 \\
\hline 4.0 & 1.89 & 4.0 & 3.67 & 4.0 & 5.79 & 4.0 & 20.79 \\
\hline 5.0 & 1.84 & 5.0 & 3.50 & 5.0 & 5.62 & 5.0 & 21.85 \\
\hline 6.0 & 1.67 & 6.0 & 3.95 & 6.0 & 5.57 & 6.0 & 22.29 \\
\hline 7.0 & 1.61 & 7.0 & 3.84 & 7.0 & 5.57 & 7.0 & 22.62 \\
\hline 8.0 & 1.67 & 8.0 & 4.06 & 8.0 & 5.68 & 8.0 & 22.79 \\
\hline 9.0 & 1.73 & 9.0 & 4.06 & 9.0 & 5.73 & 9.0 & 22.85 \\
\hline 10.0 & 1.51 & 10.0 & 4.00 & 10.0 & 5.96 & 10.0 & 22.74 \\
\hline 20.0 & 1.56 & 20.0 & 3.84 & 20.0 & 7.24 & 20.0 & $>30.90$ \\
\hline 30.0 & 1.56 & 30.0 & 3.78 & 30.0 & 7.85 & 30.0 & $>30.90$ \\
\hline 40.0 & 1.56 & 40.0 & 3.84 & 40.0 & 7.96 & 40.0 & $>30.90$ \\
\hline 50.0 & 1.62 & 50.0 & 3.84 & 50.0 & 8.18 & 50.0 & $>30.90$ \\
\hline 60.0 & 1.45 & 60.0 & 3.90 & 60.0 & 8.29 & 60.0 & $>30.90$ \\
\hline 70.0 & 1.56 & 70.0 & 3.84 & 70.0 & 8.29 & 70.0 & $>30.90$ \\
\hline 80.0 & 1.57 & 80.0 & 3.95 & 80.0 & 8.24 & 80.0 & $>30.90$ \\
\hline 90.0 & 1.68 & 90.0 & 3.95 & 90.0 & 8.24 & 90.0 & $>30.90$ \\
\hline 100.0 & 1.56 & 100.0 & 3.84 & 100.0 & 8.29 & 100.0 & $>30.90$ \\
\hline
\end{tabular}


Table 3,--Time ( $t)$, in minutes, and corresponding drawdown (s), in feet, for varied discharge rates, in gallons per minute, in well DPW during the st. Peter stepdrawdown test of March 25, 1987

\begin{tabular}{|c|c|c|c|c|c|}
\hline \multicolumn{6}{|c|}{ Discharge rate } \\
\hline \multicolumn{2}{|c|}{5} & \multicolumn{2}{|c|}{10} & \multicolumn{2}{|c|}{20} \\
\hline$t$ & s & $t$ & s & $t$ & $\mathbf{s}$ \\
\hline 0.6 & 1.22 & 0.1 & 4.22 & 0.1 & 9.51 \\
\hline $\begin{array}{r}.8 \\
1.0\end{array}$ & $\begin{array}{l}1.50 \\
1.83\end{array}$ & $\begin{array}{l}.2 \\
.4\end{array}$ & $\begin{array}{l}4.39 \\
4.83\end{array}$ & $\begin{array}{l}.2 \\
.4\end{array}$ & $\begin{array}{l}10.90 \\
11.51\end{array}$ \\
\hline 2.0 & 2.33 & .6 & 5.00 & .6 & 12.34 \\
\hline 3.0 & 2.83 & .8 & 5.22 & .8 & 12.90 \\
\hline $4 \cdot 0$ & 3.00 & 1.0 & 5.44 & 1.0 & 13.34 \\
\hline 5.0 & 3.17 & 2.0 & 6.84 & 2.0 & 15.23 \\
\hline 6.0 & 3.33 & 3.0 & 7.89 & 3.0 & 16.56 \\
\hline 7.0 & 3.39 & 4.0 & 8.79 & 4.0 & 17.34 \\
\hline 8.0 & 3.45 & 5.0 & 9.22 & 5.0 & 17.73 \\
\hline 9.0 & 3.50 & 6.0 & 9.33 & 6.0 & 18.11 \\
\hline 10.0 & 3.55 & 7.0 & 9.22 & 7.0 & 18.51 \\
\hline 20.0 & 3.67 & 8.0 & 9.06 & 8.0 & 18.89 \\
\hline 30.0 & 3.72 & 9.0 & 8.94 & 9.0 & 19.12 \\
\hline 40.0 & 3.78 & 10.0 & 8.94 & 10.0 & 19.34 \\
\hline 50.0 & 3.78 & 20.0 & 9.06 & 20.0 & 20.23 \\
\hline \multirow[t]{8}{*}{60.0} & 3.78 & 30.0 & 9.12 & 30.0 & 20.73 \\
\hline & & 40.0 & 9.23 & 40.0 & 21.11 \\
\hline & & 50.0 & 9.34 & 50.0 & 21.45 \\
\hline & & 60.0 & 9.40 & 60.0 & 21.61 \\
\hline & & 70.0 & 9.51 & 70.0 & 21.73 \\
\hline & & 80.0 & 9.51 & 80.0 & 21.95 \\
\hline & & 90.0 & 9.51 & 90.0 & 22.00 \\
\hline & & 100.0 & 9.51 & 100.0 & 22.17 \\
\hline
\end{tabular}


Barometric pressure readings, as measured at the National Oceanic and Atmospheric Administration weather station located at the Rockford airport approximately 15 miles northeast of the site, were compared with water-level altitudes. Water-level altitudes taken when the aquifers were not being pumped indicated no substantial response over the range of barometric-pressure fluctuations encountered during the aquifer tests; therefore, aquifer-test data were not corrected for barometric pressure changes.

Water levels in wells GW-16 and GW-42 were monitored hourly before, during, and after the aquifer tests using float-activated analog recorders to establish water-level trends. Well GW-16 is open to both the St. Peter and Galena-Platteville aquifers; well $\mathrm{GW}-42$ is open only to the Galena-Platteville aquifer. Problems with the recorders limited the value of the data from the off-site wells.

Pressure transducers were placed in wells MW-9, MW-18, SPW, and PZ-1 after completion of the aquifer tests to determine water-level trends when no pumping stress was taking place. Water-level data indicate that while unstressed water-level fluctuations may be substantial, they are not clearly related to time of day or temperature.

A flowmeter was connected to the discharge line to insure that discharge from the well remained constant. Periodically during the tests, discharge rates were checked by timing how long it took to fill a 55-gallon drum with water from the discharge line. Pumped water was treated and discharged to natural drainage approximately one-half mile downgradient of the salvage yard.

Galena-Platteville Aquifer Test

For the Galena-Platteville aquifer test on June 8-15, 1987, well SPW, a fully penetrating, 6-inch-diameter well, was pumped at a constant rate $(Q)$ of $19.4 \mathrm{gal} / \mathrm{min}$ for 54 hours. The pumped well, eight wells screened in the Galena-Platteville aquifer ( $\mathrm{PW}-3, \mathrm{~B}-4, \mathrm{PZ}-1, \mathrm{PZ}-2, \mathrm{~B}-3, \mathrm{~B}-5, \mathrm{MW}-8$, and $\mathrm{MW}-9)$, one well screened in both the Galena-Platteville aquifer and the Harmony Hill Shale Member $(M W-10)$, and three wells screened in the St. Peter aquifer (DPW, $G-16$, and $M W-18$ ) were monitored throughout the pumping and recovery periods (fig. 11). The raw time-drawdown data for those wells open to the GalenaPlatteville aquifer during the aquifer test are presented in table 4 . Wells B-1, B-2, and B-6 were dry when measured for months prior to and immediately before the test and were not monitored. Because the water level in the pumped well was drawn down to the pump intake approximately 43 hours into the test, air began to be drawn into the pump. Only data collected before that time were used in quantitative aquifer analysis. Recovery at the pumped well and each of the observation wells was monitored for approximately 72 hours after pumping stopped. Recovery-phase data were too erratic to accurately determine the hydraulic properties.

Several factors need to be considered in the interpretation and analysis of the aquifer-test data, including:

1. The heterogeneous nature of the fractured dolomite aquifer;

2. All the observation wells in the Galena-Platteville aquifer are partially penetrating; 


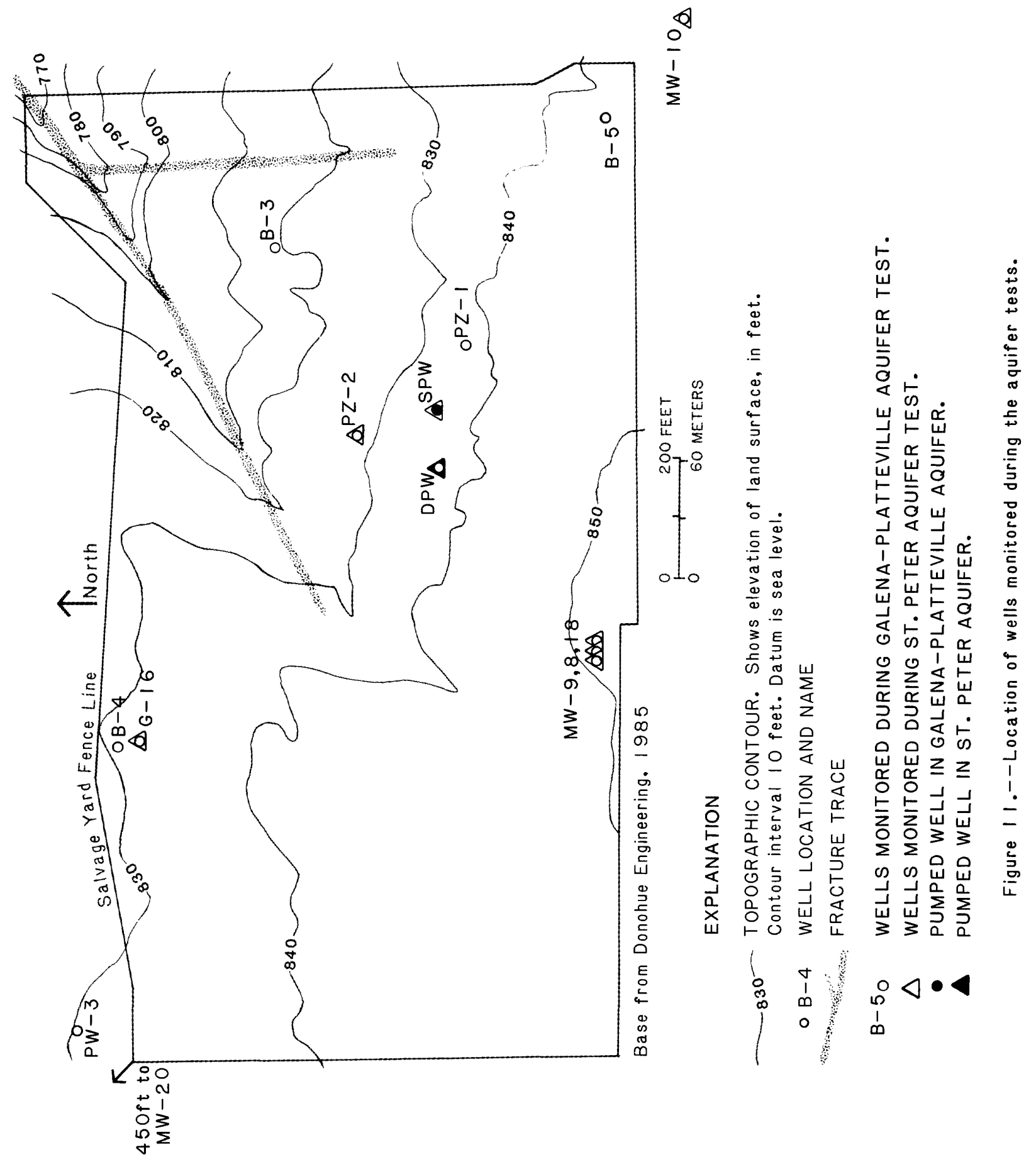


Table 4.--Time $(t)$, in minutes, and corresponding drawdown $(s)$, during the Galena-Platteville

[ - in front of the value for drawdown indicates that the water level at

\begin{tabular}{|c|c|c|c|c|c|c|c|c|c|}
\hline \multicolumn{10}{|c|}{ Wells } \\
\hline \multicolumn{2}{|c|}{ SPW } & \multicolumn{2}{|c|}{$\mathrm{PZ}-1$} & \multicolumn{2}{|c|}{ PW-3 } & \multicolumn{2}{|c|}{$B-4$} & \multicolumn{2}{|c|}{$M W-8$} \\
\hline$t$ & $\mathbf{s}$ & $t$ & $\mathbf{s}$ & $t$ & $\mathbf{s}$ & $t$ & $\mathbf{s}$ & $t$ & $\mathbf{s}$ \\
\hline 0.1 & 19.95 & 0.9 & 0.012 & 25 & 0.010 & 22 & 0.017 & 220 & 0.010 \\
\hline .2 & 19.82 & 1.0 & .014 & 30 & .013 & 26 & .021 & 340 & .030 \\
\hline $\begin{array}{r}.3 \\
.4\end{array}$ & $\begin{array}{l}20.71 \\
21.70\end{array}$ & $\begin{array}{l}1.5 \\
2.0\end{array}$ & $\begin{array}{l}.032 \\
.052\end{array}$ & $\begin{array}{l}35 \\
40\end{array}$ & $\begin{array}{l}.013 \\
.026\end{array}$ & $\begin{array}{l}30 \\
40\end{array}$ & $\begin{array}{l}.024 \\
.038\end{array}$ & $\begin{array}{l}450 \\
570\end{array}$ & $\begin{array}{l}.046 \\
.057\end{array}$ \\
\hline .5 & 21.57 & 2.5 & .072 & 45 & .030 & 50 & .040 & 670 & .073 \\
\hline .6 & 21.64 & 3.0 & .093 & 50 & .029 & 60 & .039 & 780 & .089 \\
\hline .7 & 21.61 & 3.5 & .111 & 55 & .028 & 70 & .043 & 900 & .117 \\
\hline .8 & 21.68 & 4.0 & .130 & 60 & .029 & 80 & .041 & 1,000 & .134 \\
\hline .9 & 21.82 & 4.5 & .148 & 70 & .035 & 90 & .054 & 1,080 & .143 \\
\hline 1.0 & 21.71 & 5.0 & .165 & 75 & .036 & 100 & .055 & 1,220 & .169 \\
\hline 1.5 & 22.58 & 6.0 & . 198 & 85 & .037 & 230 & .106 & 1,360 & .191 \\
\hline 2.0 & 23.64 & 7.0 & .254 & 90 & .036 & 330 & .159 & 1,540 & .207 \\
\hline 2.5 & 22.75 & 8.0 & .277 & 95 & .037 & 430 & .215 & 1,750 & .221 \\
\hline 3.0 & 22.73 & 9.0 & .299 & 100 & .038 & 560 & .228 & 2,140 & .219 \\
\hline 3.5 & 22.66 & 10 & .319 & 105 & .039 & 660 & .256 & 2,270 & .303 \\
\hline 4.0 & 22.91 & 20 & .509 & 110 & .041 & 770 & .271 & 2,460 & .338 \\
\hline 4.5 & 22.49 & 30 & .687 & 280 & .082 & 890 & .304 & 2,600 & .355 \\
\hline 5.0 & 21.79 & 40 & .754 & 340 & .096 & 980 & .321 & 2,850 & .392 \\
\hline 6.0 & 21.36 & 50 & .774 & 460 & .110 & 1,070 & .343 & 3,130 & .414 \\
\hline 7.0 & 21.22 & 60 & .783 & 570 & .120 & 1,200 & .391 & -- & -- \\
\hline 8.0 & 20.32 & 70 & .788 & 680 & .128 & 1,350 & .432 & -- & -- \\
\hline 9.0 & 21.15 & 80 & .791 & 790 & .148 & 1,530 & .457 & -- & -- \\
\hline 10 & 22.36 & 90 & .800 & 900 & .170 & 1,730 & .461 & -- & -- \\
\hline 20 & 31.42 & 100 & .805 & 1,000 & .212 & 2,140 & .371 & -- & -- \\
\hline 30 & 34.87 & 230 & .842 & 1,100 & .219 & 2,290 & .409 & -- & -- \\
\hline 40 & 35.70 & 320 & .860 & 1,220 & .235 & 2,480 & .431 & -- & -- \\
\hline 50 & 35.63 & 410 & .877 & 1,370 & .254 & 2,610 & .407 & -- & -- \\
\hline 60 & 35.70 & 450 & .883 & 1,550 & .279 & 2,900 & .417 & -- & -- \\
\hline 70 & 35.84 & 530 & .891 & 1,750 & .293 & 3,140 & .441 & -- & -- \\
\hline 80 & 36.17 & 630 & .903 & 2,150 & .334 & -- & -- & -- & -- \\
\hline
\end{tabular}


in feet, for the wells open to the Galena-platteville aquifer aquifer test of June $8-15,1987$

that time is higher than the initial water level; -- indicates no data]

\begin{tabular}{|c|c|c|c|c|c|c|c|c|c|}
\hline \multicolumn{10}{|c|}{ Wells } \\
\hline \multicolumn{2}{|c|}{ MW-9 } & \multicolumn{2}{|c|}{$B-3$} & \multicolumn{2}{|c|}{$B-5$} & \multicolumn{2}{|c|}{$P Z-2$} & \multicolumn{2}{|c|}{$M W-10$} \\
\hline$t$ & $s$ & $t$ & $\mathbf{s}$ & $t$ & $\mathbf{s}$ & $t$ & $\mathbf{s}$ & $t$ & s \\
\hline 450 & 0.010 & 330 & 0.01 & 240 & 0.010 & 100 & 0.020 & 269 & 0.025 \\
\hline 570 & .020 & 540 & .02 & 340 & .060 & 230 & .060 & 350 & .012 \\
\hline 670 & .014 & 700 & .07 & 430 & .095 & 320 & .090 & 477 & .038 \\
\hline 780 & .029 & 790 & .07 & 540 & .129 & 440 & .193 & 582 & .045 \\
\hline 900 & .043 & 910 & .10 & 660 & .170 & 540 & .235 & 685 & .060 \\
\hline 1,000 & .048 & 980 & .11 & 780 & .205 & 610 & .277 & 797 & .087 \\
\hline 1,080 & .051 & 1,075 & .12 & 800 & .208 & 800 & .315 & 910 & .087 \\
\hline 1,220 & .055 & 1,210 & .13 & 890 & .231 & 880 & .329 & 1,019 & .178 \\
\hline 1,360 & .055 & 1,360 & .12 & 920 & .238 & 980 & .345 & 1,230 & . 154 \\
\hline 1,540 & .054 & 1,540 & .08 & 1,000 & .258 & 1,070 & .353 & 1,375 & .184 \\
\hline 1,750 & .090 & 1,790 & .07 & 1,090 & .266 & 1,200 & .293 & 1,556 & .189 \\
\hline 2,140 & .093 & 2,110 & .07 & 1,220 & .237 & 1,360 & .169 & 1,765 & .132 \\
\hline 2,270 & .127 & 2,280 & .06 & 1,350 & .204 & 1,540 & .084 & 2,161 & .184 \\
\hline 2,480 & .138 & 2,465 & .04 & 1,530 & .173 & 1,790 & .114 & 2,511 & .266 \\
\hline 2,600 & .144 & 2,600 & .02 & 1,750 & .239 & 2,100 & .059 & 2,648 & .243 \\
\hline 2,850 & .145 & 2,830 & -.01 & 2,110 & .207 & 2,290 & .020 & 2,888 & .211 \\
\hline 3,130 & .152 & 3,130 & -.12 & 2,250 & .202 & 2,410 & .010 & 3,140 & .201 \\
\hline-- & -- & -- & -- & 2,470 & . 199 & 2,540 & -.020 & -- & -- \\
\hline-- & -- & -- & -- & 2,630 & .150 & 2,600 & -.075 & -- & -- \\
\hline-- & -- & -- & -- & 2,840 & .081 & 2,820 & -.220 & -- & -- \\
\hline-- & -- & -- & -- & 3,130 & .046 & 3,130 & -.310 & -- & -- \\
\hline-- & -- & -- & -- & -- & -- & -- & -- & -- & -- \\
\hline-- & -- & -- & -- & -- & -- & -- & -- & -- & -- \\
\hline-- & -- & -- & -- & -- & -- & -- & -- & -- & -- \\
\hline-- & -- & -- & -- & -- & -- & -- & -- & -- & -- \\
\hline-- & -- & -- & -- & -- & -- & -- & -- & -- & -- \\
\hline-- & -- & -- & -- & -- & -- & -- & -- & -- & -- \\
\hline-- & -- & -- & -- & -- & -- & -- & -- & -- & -- \\
\hline-- & -- & -- & -- & -- & -- & -- & -- & -- & -- \\
\hline-- & -- & -- & -- & -- & -- & -- & -- & -- & -- \\
\hline
\end{tabular}


Table 4.--Time $(t)$, in minutes, and corresponding drawdown (s), during the Galena-Platteville aquifer

\begin{tabular}{|c|c|c|c|c|c|c|c|c|c|}
\hline \multicolumn{10}{|c|}{ Wells } \\
\hline \multicolumn{2}{|c|}{ SPW } & \multicolumn{2}{|c|}{$\mathrm{PZ}-1$} & \multicolumn{2}{|c|}{$P W-3$} & \multicolumn{2}{|c|}{ B-4 } & \multicolumn{2}{|c|}{ MW-8 } \\
\hline$t$ & $\mathbf{s}$ & $t$ & $\mathbf{s}$ & $t$ & $\mathbf{s}$ & $t$ & $\mathbf{s}$ & $t$ & $\mathbf{s}$ \\
\hline 90 & 36.28 & 810 & .946 & 2,500 & .412 & -- & -- & -- & -- \\
\hline 100 & 36.70 & 890 & .969 & 2,650 & .431 & -- & -- & -- & -- \\
\hline 200 & 35.93 & 980 & .980 & 2,880 & .457 & -- & -- & -- & -- \\
\hline 300 & 36.12 & 1,070 & .976 & 3,140 & .492 & - & -- & -- & -- \\
\hline 400 & 35.84 & 1,190 & .991 & -- & -- & -- & -- & -- & -- \\
\hline 500 & 36.60 & 1,350 & 1.006 & -- & -- & -- & -- & -- & -- \\
\hline 600 & 36.32 & 1,525 & 1.031 & -- & -- & -- & -- & -- & -- \\
\hline 700 & 36.95 & 1,720 & 1.065 & - & -- & -- & -- & -- & -- \\
\hline 800 & 39.78 & 2,130 & 1.085 & -- & -- & -- & -- & -- & -- \\
\hline 900 & 39.76 & 2,250 & 1.114 & -- & -- & -- & -- & -- & -- \\
\hline 1,000 & 39.77 & 2,400 & 1.136 & -- & -- & -- & -- & -- & -- \\
\hline 1,200 & 39.78 & 2,500 & 1.149 & -- & -- & -- & -- & -- & -- \\
\hline 1,400 & 40.21 & 2,600 & 1.159 & -- & -- & -- & -- & -- & -- \\
\hline 1,600 & 40.56 & 2,810 & 1.175 & -- & -- & -- & -- & -- & -- \\
\hline 1,800 & 41.05 & 3,140 & 1.204 & -- & -- & -- & -- & -- & -- \\
\hline 2,000 & 41.36 & -- & -- & -- & -- & -- & -- & -- & -- \\
\hline 2,500 & 42.00 & -- & -- & -- & -- & -- & -- & -- & -- \\
\hline 2,570 & $>43.04$ & -- & -- & -- & -- & -- & -- & -- & -- \\
\hline 3,140 & $>43.04$ & -- & -- & -- & -- & -- & -- & -- & -- \\
\hline
\end{tabular}


feet, for the wells open to the Galena-Platteville aquifer test of June 8-15, 1987--Continued

\begin{tabular}{|c|c|c|c|c|c|c|c|c|c|}
\hline \multicolumn{10}{|c|}{ Wells } \\
\hline \multicolumn{2}{|c|}{ MW-9 } & \multicolumn{2}{|c|}{$B-3$} & \multicolumn{2}{|c|}{$B-5$} & \multicolumn{2}{|c|}{$P Z-2$} & \multicolumn{2}{|c|}{ MW-10 } \\
\hline$t$ & $\mathbf{s}$ & $t$ & $\mathbf{s}$ & $t$ & s & $t$ & $\mathbf{s}$ & $t$ & $\mathbf{s}$ \\
\hline-- & -- & -- & - & -- & -- & -- & -- & -- & -- \\
\hline-- & -- & -- & -- & -- & -- & -- & -- & -- & -- \\
\hline-- & -- & -- & -- & -- & -- & -- & -- & -- & -- \\
\hline-- & -- & -- & -- & -- & -- & -- & -- & -- & -- \\
\hline-- & -- & -- & -- & -- & -- & -- & -- & -- & -- \\
\hline-- & -- & -- & -- & -- & -- & -- & -- & -- & -- \\
\hline-- & -- & -- & -- & -- & -- & -- & -- & -- & -- \\
\hline-- & -- & -- & -- & -- & -- & -- & -- & -- & -- \\
\hline-- & -- & -- & -- & -- & -- & -- & -- & -- & -- \\
\hline-- & -- & -- & -- & -- & -- & -- & -- & -- & -- \\
\hline-- & -- & -- & -- & -- & -- & -- & -- & -- & -- \\
\hline-- & -- & -- & -- & -- & -- & -- & -- & -- & -- \\
\hline-- & -- & -- & -- & -- & -- & -- & -- & -- & -- \\
\hline-- & -- & -- & -- & -- & -- & -- & -- & -- & -- \\
\hline-- & -- & -- & -- & -- & -- & -- & -- & -- & -- \\
\hline-- & -- & -- & -- & -- & -- & -- & -- & -- & -- \\
\hline-- & -- & -- & -- & -- & -- & -- & -- & -- & -- \\
\hline-- & -- & -- & -- & -- & -- & -- & -- & -- & -- \\
\hline-- & -- & -- & -- & -- & -- & -- & -- & -- & -- \\
\hline
\end{tabular}


3. Extensive dewatering in the vicinity of the pumped well occurred during the test (approximately 50 percent of the saturated thickness of the aquifer); and

4. Relatively steep water-table gradients exist near the pumped well (see fig. 9).

Before beginning analysis of the aquifer-test data, it is important to note the limitations of the data. Drawdown-data corrections necessitated by the effects of partially penetrating observation wells could not be applied because of the heterogeneous and anisotropic nature of the aquifer. It may be assumed, however, that transmissivity values derived from time-drawdown data from partially penetrating wells are somewhat lower than if the wells had been fully penetrating. Water levels in partially penetrating wells indicate hydraulic head conditions only at the screened interval of the well and, therefore, may not represent the entire hydraulic stress that is imparted to the aquifer by the fully penetrating pumped well. This may be particularly important in fractured aquifers where the screened intervals of observation wells do not penetrate water-bearing zones that contribute a substantial amount of water to the pumped well. Extensive dewatering in the vicinity of the pumped well and its effect on well-loss computations (Eagon and Johe, 1972 , p. 8) prevented quantitative analysis of the pumped-well data. No data corrections were applied due to sloping water-table conditions, although the water-table configuration was considered in qualitative interpretations of observation well response.

The Galena-Platteville aquifer consists of two media, fractures and porous rock, each with different hydraulic properties. Therefore, the doubleporosity model for unconfined aquifers (Boulton and streltsova-Adams, 1978) was used as both a conceptual and analytical model in data analysis and interpretation.

The main conditions assumed in the double-porosity model are as follows:

1. The pumped well is fully penetrating.

2. The pumped well discharges at a constant rate, $Q$, beginning at time $t=0$.

3. The radius of the pumped well is infinitesimal.

4. Fractured aquifers consist of block and fissured units. Each unit is assumed to consist of a block of some width (H) and permeability (k2) which is overlain by a horizontal fissure of some width (h) and permeability (k1).

5. Fissures and blocks are compressible.

6. Flow in the blocks is vertical.

7. Flow in fissures is horizontal.

8. The pressure differential due to the different elastic properties of blocks and fissures results in the water exchange between blocks and fissures (Boulton and streltsova-Adams, 1978, p. 351).

Each of these assumptions is met or approximated at the salvage yard. 
On the basis of these assumptions, it is apparent that the response of water levels in observation wells due to pumping depends on several factors including:

1. The number of fractures intersected by the screened interval of the observation well;

2. The degree of fracture interconnection between the pumped well and the observation well;

3. The size of the porous blocks relative to the size of the fractures; and

4. The hydraulic conductivity and storage coefficient of the fractures and porous rock.

The caliper log of well SPW in figure 12 shows that there are two fractured zones from which the well will obtain water--the upper fracture zone at approximately 85 to $107 \mathrm{ft}$ and the lower fracture zone at approximately 125 to $130 \mathrm{ft}$. Drawdown data from well SPW (table 4) indicate that the upper fracture zone was dewatered within the first few minutes of the aquifer test; therefore, the majority of the discharge was derived from the lower fracture zone. Because the majority of flow is coming from the lower fracture, it can be predicted that those wells in good hydraulic connection with this zone will have the largest amount of drawdown, whereas those wells that are not in good connection will experience the least amount of drawdown.

Because the fractures in the pumped well have been at least partly filled with clays (compare the natural gamma and three-arm caliper logs in figure 12), the hydraulic connection of the pumped well with the aquifer may change with pumping. If pumping removes clays from the fractures, hydraulic connection with the aquifer will increase. If pumping causes clays to plug up the fracture, hydraulic connection will decrease.

The magnitude of drawdown and response time of the observation wells are not simple functions of the radial distance $(r)$ between the observation well and the pumped well as can be seen in figure 13. Rather, the magnitude of drawdown and response time are related to the degree of hydraulic connection between the pumped and observation wells. More specifically, the magnitude of drawdown and response time are related to the degree of hydraulic connection between the lower fracture zone in the pumped well and the open interval of the observation well. Wells $\mathrm{PZ}-1, \mathrm{~B}-4$, and $\mathrm{PW}-3$ seem to be in good hydraulic connection with the pumped well, whereas wells MW-8 and MW-9 seem to be in comparatively poor hydraulic connection with the pumped well. However, well MW-8 is in better hydraulic connection than is MW-9. The directional nature of the hydraulic connection within the Galena-Platteville aquifer can be seen in figure 14, which shows the drawdown of the water table at 1,000 minutes into the test. The major axis of the drawdown trough is parallel to the dominant regional fracture orientation (N. $60^{\circ}$ W.).

The response of the Galena-Platteville aquifer to pumping changed while the aquifer test was in progress. During the first 1,100 minutes of the aquifer test, the drawdown distribution in the Galena-Platteville aquifer seemed to be that of a homogeneous, anisotropic aquifer (fig. 14). After approximately 


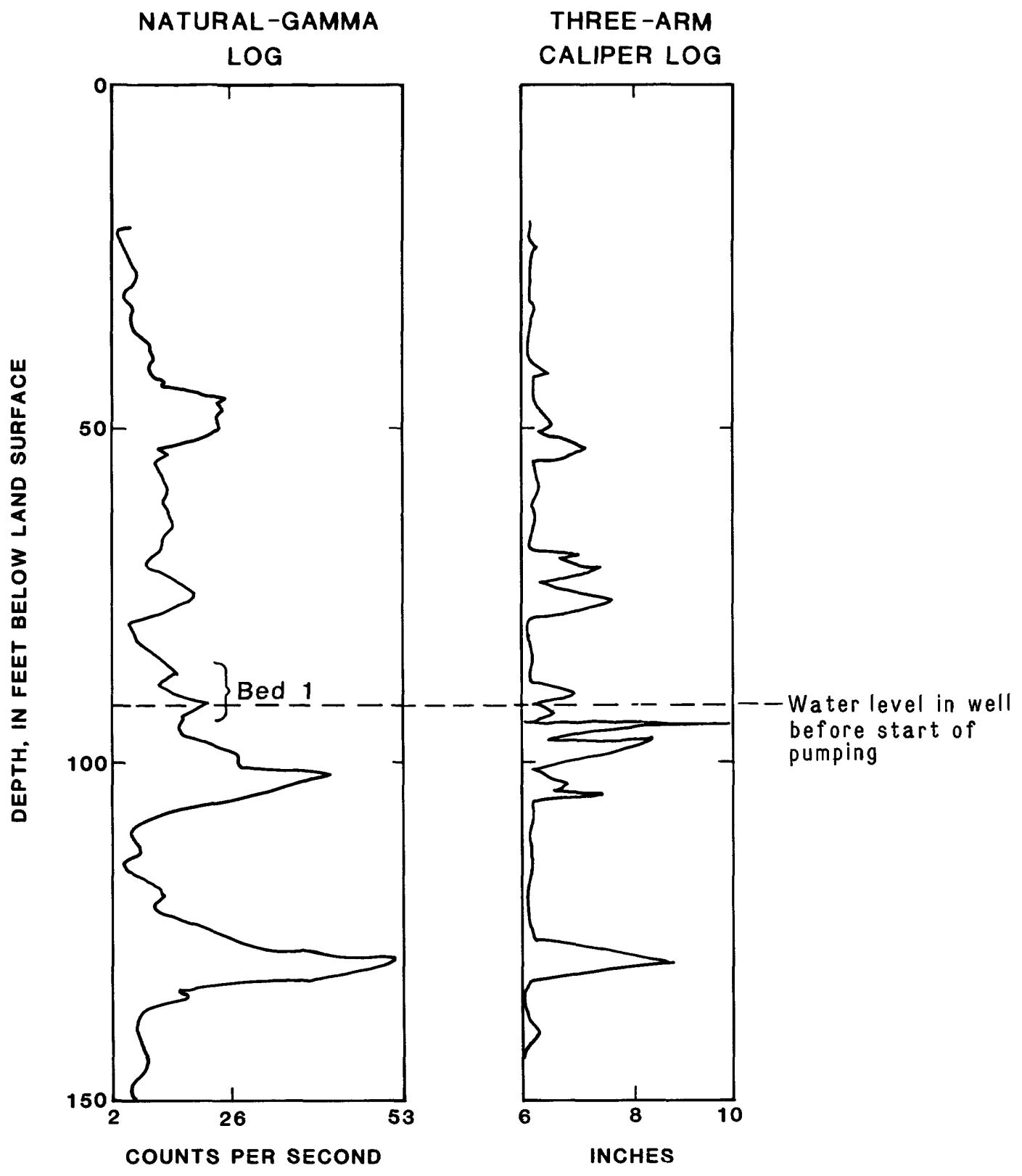

Figure 12.--Natural gamma-log and three-arm caliper log for observation well SPW. 


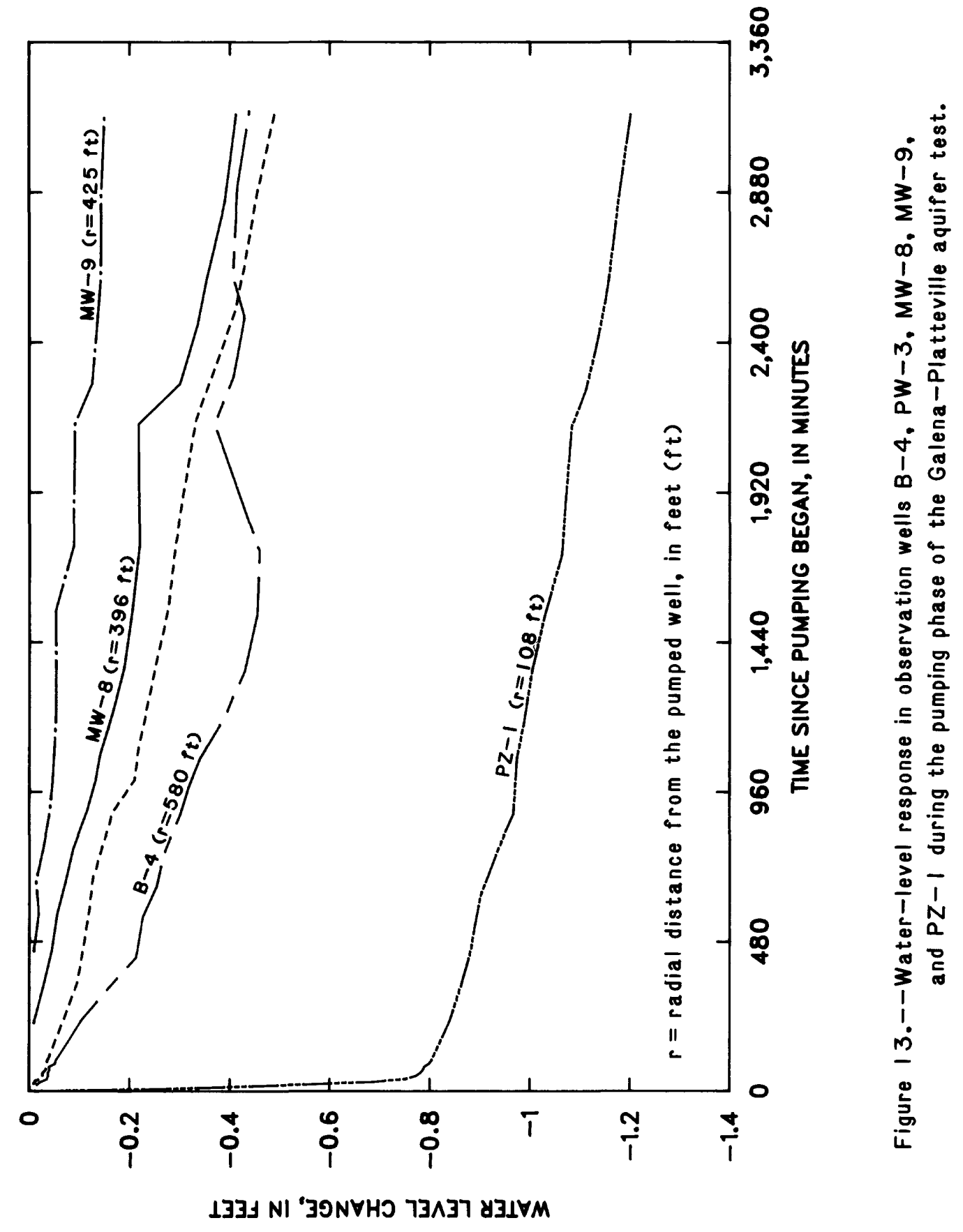




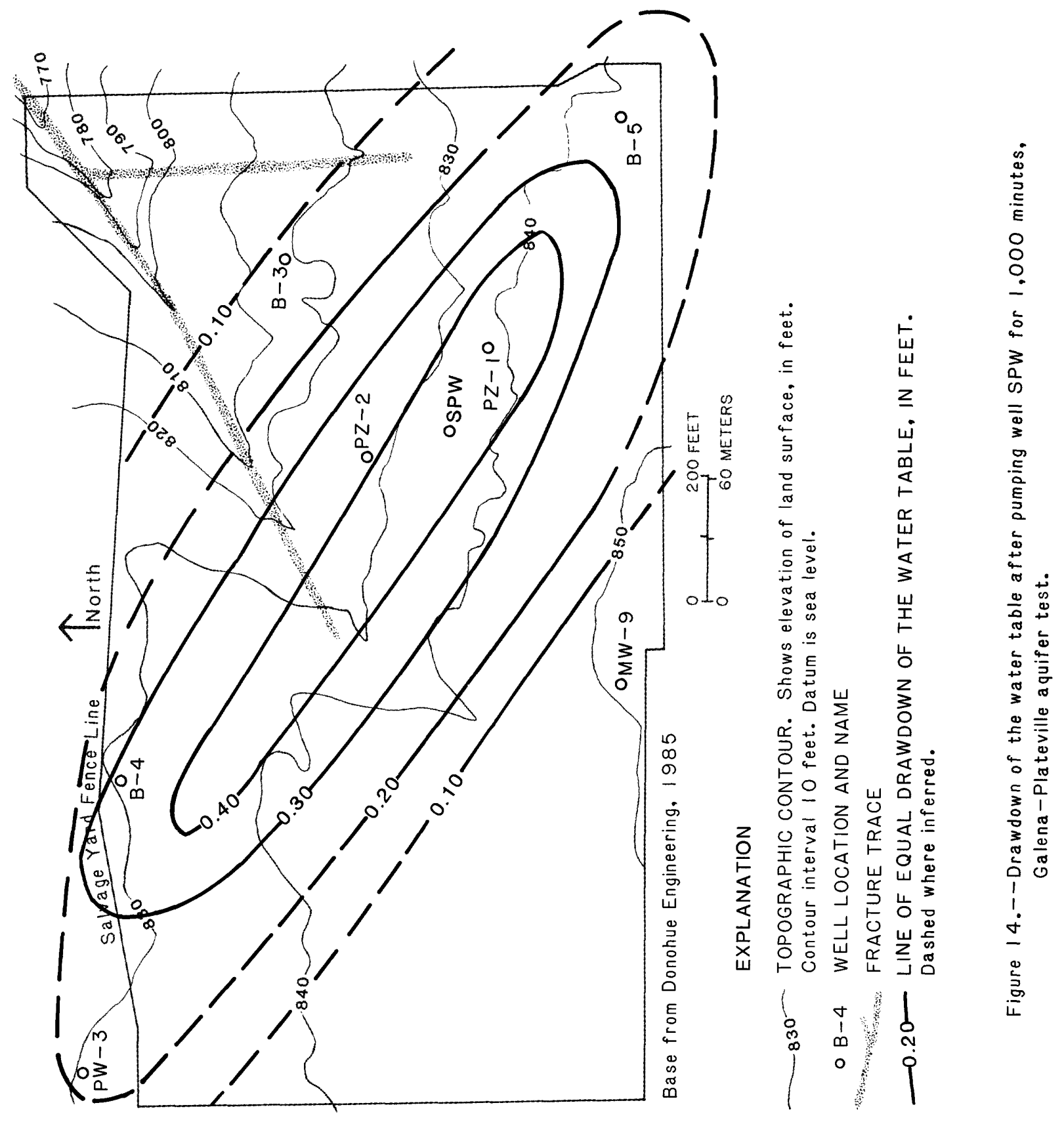


1,100 minutes, water levels in wells B-3, B-5, PZ-2, and well MW-10 rose (fig. 15). Although the water level in well $\mathrm{MW}-10$ responded differently, water levels in wells $\mathrm{B}-3, \mathrm{~B}-5$, and $\mathrm{PZ}-2$ reached their pretest levels before the end of the pumping phase of the aquifer test and continued to increase throughout the recovery phase. Conversely, water levels in wells B-4, PZ-1, MW-8, MW-9, and $\mathrm{PW}-3$ never reached pretest levels during the pumping or recovery phases. The fact that the wells in different areas of the aquifer responded differently to pumping is further indication that the aquifer is both heterogeneous and anisotropic, confirming the conclusions drawn from the water-level data.

Thorough inspection of aquifer-test and regional water-level data revealed no conclusive evidence as to the nature of the hydrologic stresses that caused the anomalous water-level response in wells B-3, B-5, and PZ-2. However, assuming that the law of superposition applies and may be used to describe observation well characteristics, it is clear that the water-level rise in these wells during pumping must be the result of hydraulic stresses other than those induced by pumping. Either the aquifer in the area of wells B-3, B-5, and PZ-2 became hydraulically isolated from the lower fracture zone in the pumped well and the water-level rise is due simply to recovery from pumping stress, or a hydraulic stress other than pumping was felt in this area. Whatever the cause of the hydraulic stress, or the lack thereof, it seems clear that wells $\mathrm{B}-3, \mathrm{~B}-5$, and $\mathrm{PZ}-2$ were subjected to its influence and the other wells were not, or at least did not respond in the same way. Interestingly, water-level response in wells in the St. Peter aquifer during the GalenaPlatteville aquifer test (fig. 16) showed a trend similar to that of wells B-3, B-5, and PZ-2 (compare figs. 15 and 16). This similarity in water-level response may indicate that the phenomena responsible for water-level changes in wells B-3, B-5, and PZ-2 may also have affected wells in the St. Peter aquifer.

Time-drawdown plots of pumpage data were constructed on a log-log scale and compared to type curves of the Boulton and Streltsova-Adams model (1978). Transmissivity $(T)$ and specific yield (SY) were calculated from the data at the match point common to the field data curve and the type curve when they are matched (fig. 17). Water levels in wells PZ-1, B-4, MW-8, MW-9, and PW-3 declined almost continuously during the aquifer test and provided the best data for curve matching. The comparatively small amount of drawdown in well MW-9 may limit the accuracy of the curve match. The data plots for wells PZ-1, $\mathrm{B}-4$, and $\mathrm{PW}-3$, along with the type curves used in the analysis, are shown in figures 17, 18, and 19. Time-drawdown data from well MW-10 was too erratic to provide even a rough curve match.

Calculated horizontal hydraulic conductivity, transmissivity, and specific yield for wells $\mathrm{PZ}-1, \mathrm{~B}-4, \mathrm{MW}-8, \mathrm{MW}-9$, and $\mathrm{PW}-3$ are presented in table 5. The accuracy of hydraulic conductivity values in fractured rock is limited without detailed information on the fracture density and aperture. If it is assumed that the dolomite can be characterized as an equivalent porous media, then the horizontal hydraulic conductivity calculated for these wells ranges from 5.8 to $8.7 \mathrm{ft} / \mathrm{d}$. Estimated transmissivity values for these wells range from 490 to $670 \mathrm{ft}^{2} / \mathrm{d}$ (feet squared per day); the average transmissivity is $660 \mathrm{ft}^{2} / \mathrm{d}$ at the wells oriented along a line approximately parallel with the dominant fracture orientation and direction of preferential flow in the dolomite and 


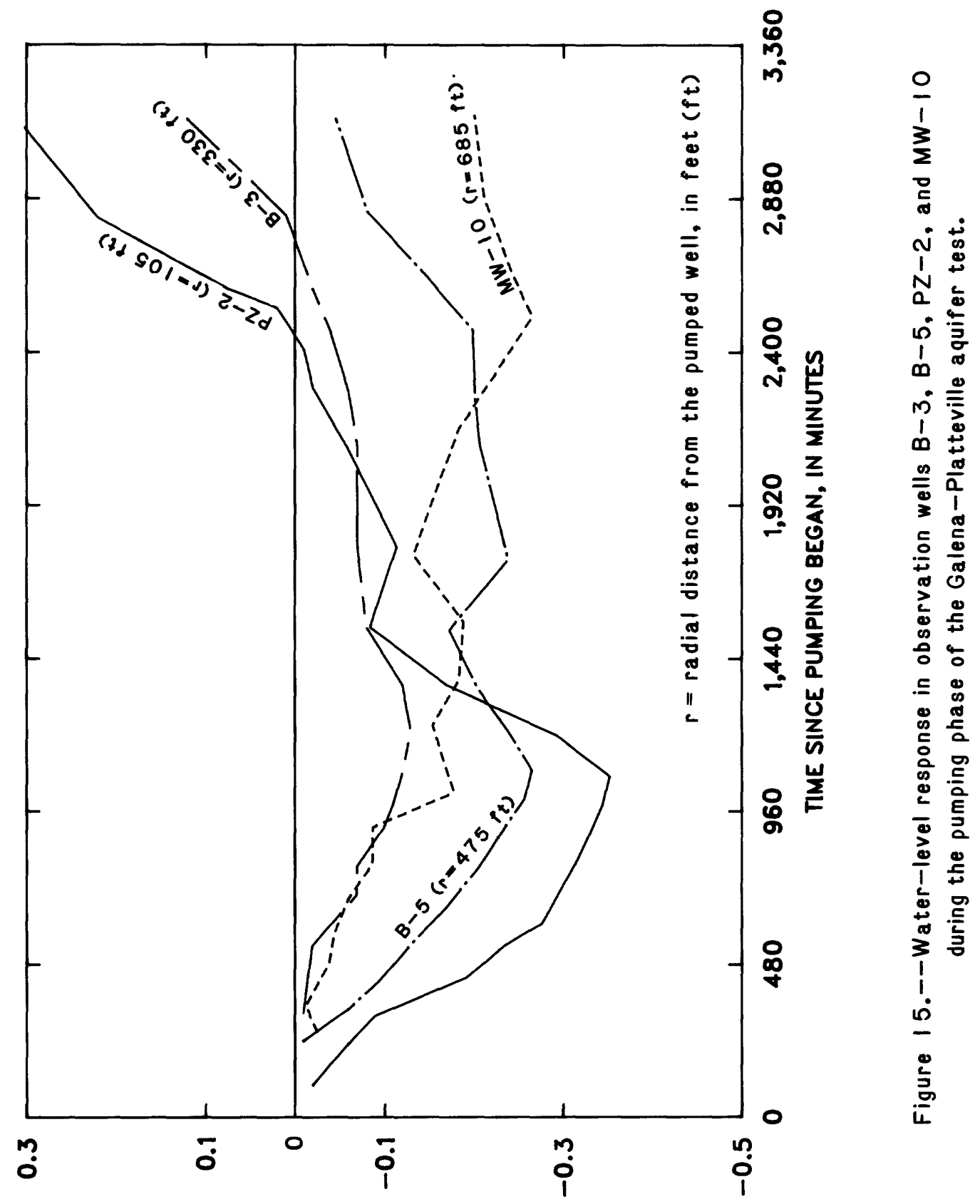

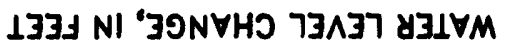




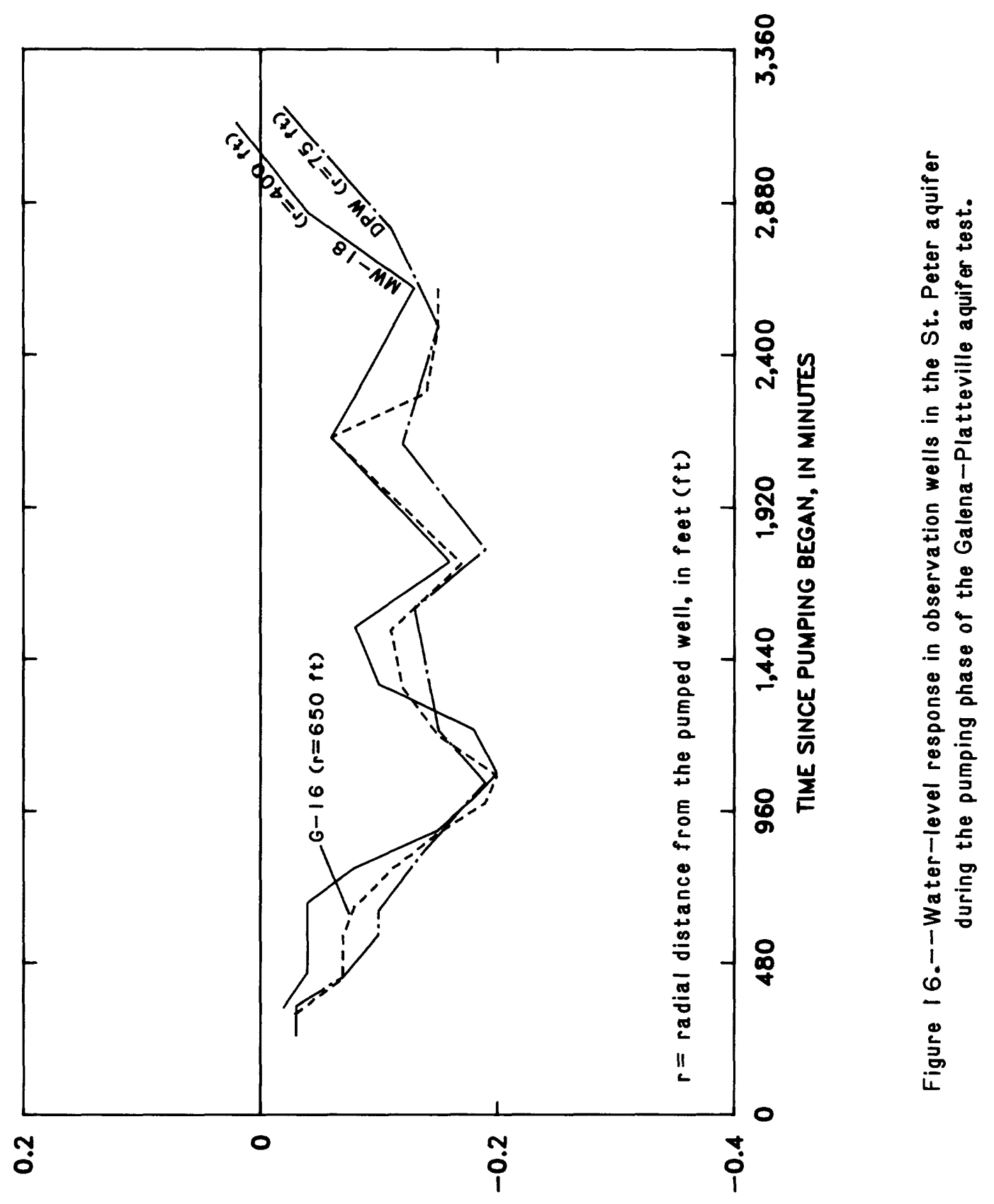

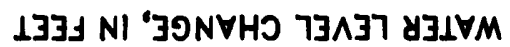




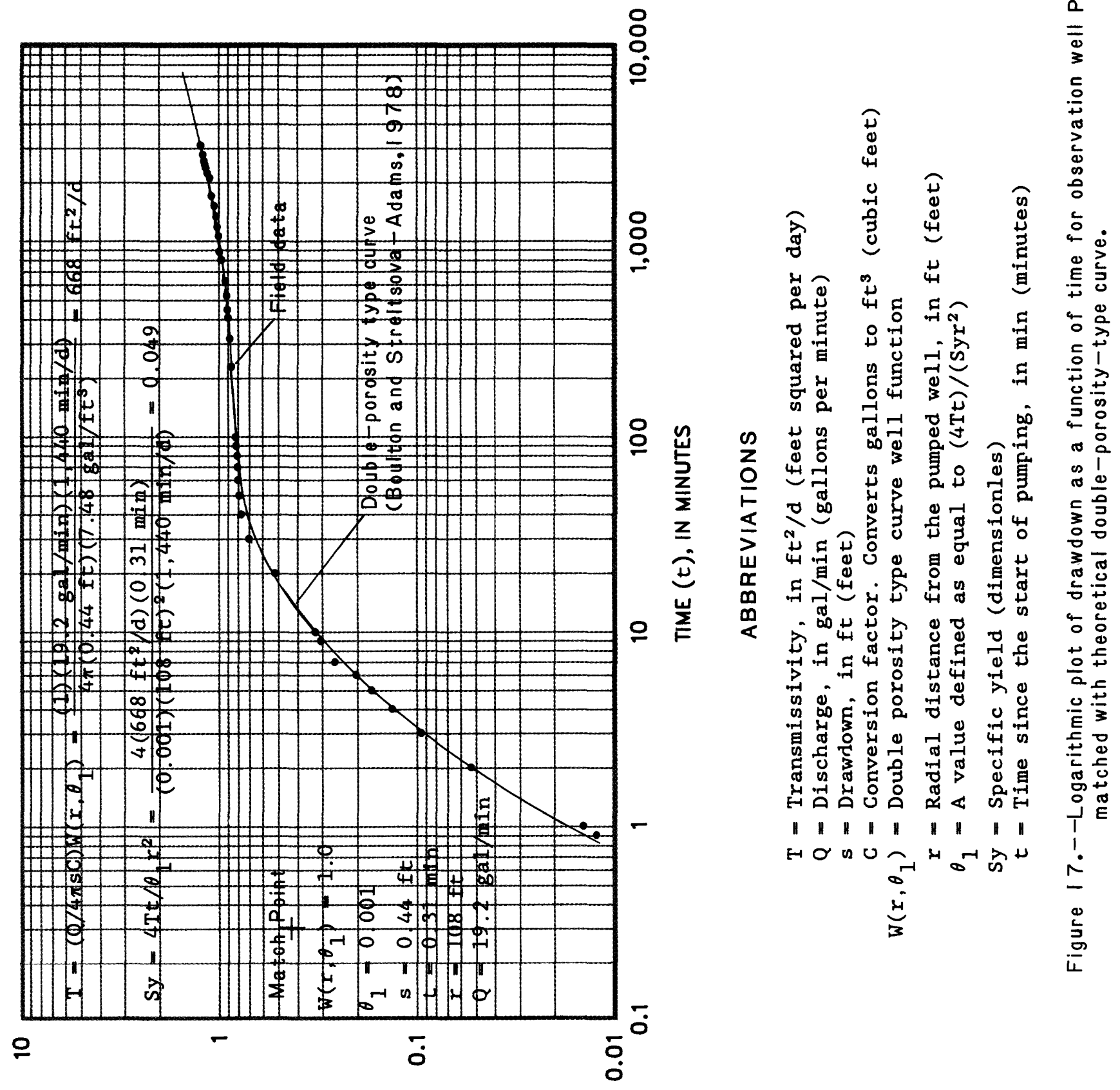

$1 \exists \exists$ ل NI "(s) NMOOMVYO 

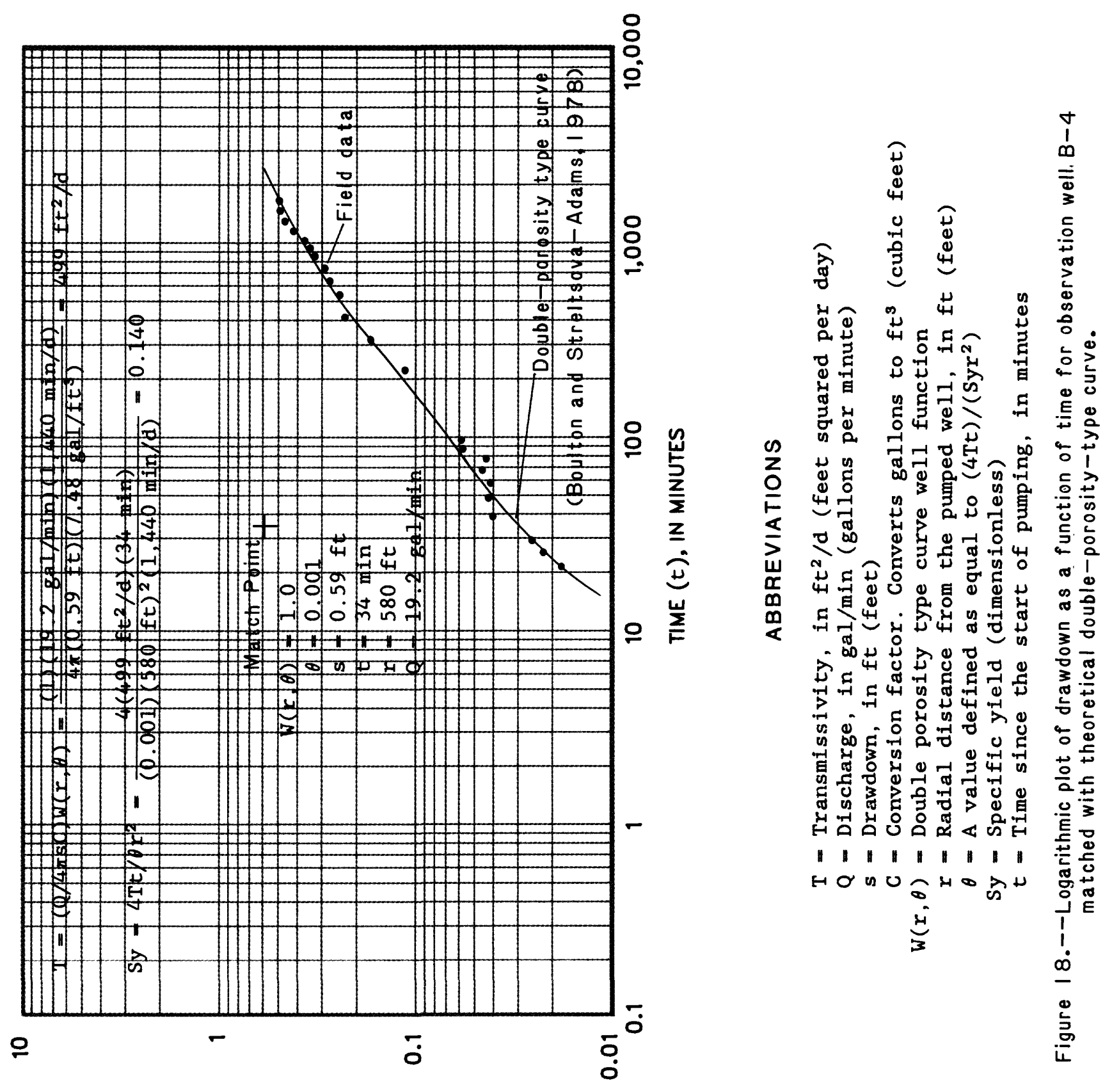

$13 \exists J$ NI "(s) NMOOMVYO 

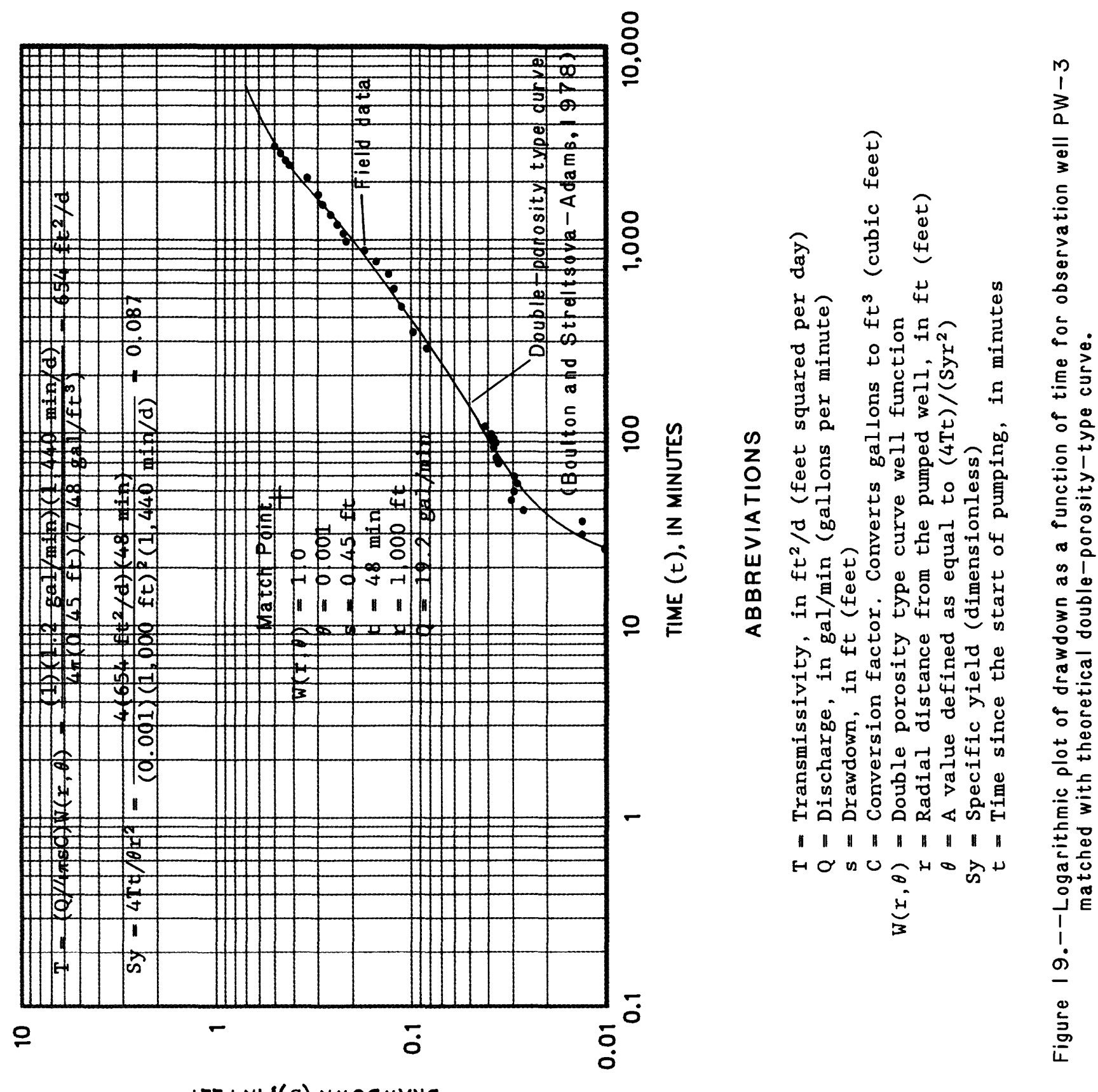

$13 \exists$ ل NI "(s) NMOOMVYO 
Table 5.--Estimated horizontal hydraulic conductivity, transmissivity, and specific yields from the Galena-Platteville aquifer test of June $8-15,1987$

$\left[f t / d\right.$, feet per day; $f t^{2} / d$, feet squared per day]

\begin{tabular}{lccc}
\hline $\begin{array}{l}\text { Well } \\
\text { name }\end{array}$ & $\begin{array}{c}\text { Hydraulic } \\
\text { conductivity } \\
(\mathrm{ft} / \mathrm{d})\end{array}$ & $\begin{array}{c}\text { Transmissivity } \\
\left(\mathrm{ft}^{2} / \mathrm{d}\right)\end{array}$ & $\begin{array}{c}\text { Specific } \\
\text { yield }\end{array}$ \\
\hline PZ-1 & 8.0 & 670 & 0.049 \\
B-4 & 6.7 & 500 & .140 \\
PW-3 & 8.7 & 650 & .087 \\
MW-8 & 5.8 & 490 & .017 \\
MW-9 & 5.8 & 490 & .023 \\
\hline
\end{tabular}

$490 \mathrm{ft}^{2} / \mathrm{d}$ at the wells perpendicular to the dominant fracture orientation and direction of preferential flow. The specific yield of these wells ranges from 0.017 to 0.140 . Transmissivity values are a function of fracture flow within the aquifer, whereas the storage-coefficient values are indicative of values for porous dolomite.

Because of the anomalous response of wells B-3, B-5, and PZ-2 to pumping, time-drawdown plots of these wells extended less than one log cycle on the time axis. This limited the accuracy and validity of the curve-matching process for these wells. The estimated transmissivity for wells $\mathrm{B}-5, \mathrm{~B}-3$, and $\mathrm{PZ}-2$ are 230,320 , and $390 \mathrm{ft}^{2} / \mathrm{d}$, respectively. The lack of any consistent relation between transmissivity and direction from the pumped well for wells B-5, B-3, and PZ-2 indicates either that the aquifer is both anisotropic and heterogeneous or that partial penetration, the high water-table slope, and whatever forces are responsible for the water-level rise in these wells, are having a significant effect on the time-drawdown data.

\section{St. Peter Aquifer Test}

For the St. Peter aquifer test on May 27-30, 1987, well DPW, a 6-inchdiameter well that penetrates $120 \mathrm{ft}$ of the approximately 420-ft-thick St. Peter aquifer was pumped at a rate $(Q)$ of $23 \mathrm{gal} / \mathrm{min}$ for 48 hours and allowed to recover for 48 hours. Two wells screened in the st. Peter aquifer (MW-18 and G-16) and the pumped well (fig. 11) were monitored during the pumping and recovery phases of the test to determine the transmissivity (T), storativity ( $\left.S^{\prime}\right)$, and horizontal hydraulic conductivity of the aquifer and the leakage $\left(\mathrm{k}^{\prime} / \mathrm{b}^{\prime}\right)$ through the Harmony Hill Shale Member. Water levels in five wells (SPW, MW-8, MW-9, B-3, and PZ-2) screened in the Galena-Platteville aquifer and one well (MW-10) screened in both the Galena-Platteville aquifer and the Harmony Hill Shale Member were monitored to determine the degree of hydraulic connection between the st. Peter and Galena-Platteville aquifers. 
Water levels in well MW-20 were monitored to determine background water-level changes in the aquifer. Interference due to pumping from two deep wells (open below the St. Peter aquifer) located at the Byron Station Nuclear Power plant, approximately $1 \frac{1}{2}$ miles southeast of the site (fig. 1), was determined to be insignificant because measurements collected to establish water-level trends showed no correlation with pumping at the plant. Raw time-drawdown data from all of the wells open to the St. Peter aquifer are presented in table 6 .

Before the aquifer-test data could be analyzed, corrections had to be made to eliminate the effects of partial penetration of the pumped well (Walton, 1978, p. 31). Drawdowns in wells MW-18 and G-16 were corrected for partial penetration using methods presented in Walton (1962, p. 7-8). Drawdown data for the pumped well were corrected for partial penetration and well loss using methods outlined by Walton (1962, p. 8). A well loss equal to 31 percent of drawdown in the pumped well was determined from the step-drawdown data in the st. Peter aquifer. Drawdown data were corrected for partial penetration by assuming that the St. Peter aquifer was $420 \mathrm{ft}$ thick and that the vertical and horizontal hydraulic conductivity of the aquifer was approximately equal. It was assumed that the vertical and horizontal hydraulic conductivities were approximately equal based on the St. Peter sandstone lithology.

As was the case with the Galena-Platteville aquifer test, water levels in the St. Peter aquifer rose while the aquifer was being pumped. At approximately 600 minutes into the test, the water level in the pumped well began to rise while the discharge remained constant. A 100-minute pump test was conducted after recovery had been completed to verify the assumption that the specific capacity of the pumped well was improved as a result of continuous well development during the aquifer test (Paul Karmazinski, NUS Corporation, oral commun., 1987). The specific capacity at 100 minutes into the aquifer test was 0.93 (gal/min)/ft (gallons per minute per foot), specific capacity at the end of the 100 minute pump test was 1.11 (gal/min)/ft.

Maximum drawdown occurred approximately 1,400 minutes into the pumping phase of the aquifer test. The water level at observation well MW-18 began to rise after 1,400 minutes and generally increased during the remainder of the aquifer test through the recovery phase (fig. 20). The water level in well MW-18 at the end of the recovery phase of the test was $1.42 \mathrm{ft}$ higher than at the beginning of the test. There are two possible explanations for the increased water level at well MW-18: Water-level rise represents either recovery of water level following pumping of an off-site well, or the rise represents a regional watex-level rise that overrode the effects of pumping.

Because the water levels in well G-16 did not rise, recovery of an offsite pumped well does not seem to be a likely explanation for the water-level $r$ ise at well MW-18. One would expect that recovery on the order of $0.2 \mathrm{ft}$ at wells MW-18 and MW-20 would have to have caused some water-level rise at well G-16 (table 6). Also, as stated earlier, there was no significant pumping at any off-site wells.

Water-level changes in well MW-20 tend to support a regional rise in water level. Water levels in well MW-20 show an overall rise that starts approximately 1,600 minutes into the test. Why well G-16 does not experience this 
Table 6.--Time $(t)$, in minutes, and corresponding drawdown $(s)$, in feet, for the wells open to the St. Peter aquifer during

the St. Peter aquifer test of May 27-30, 1987

[ - sign indicates that the water level at that time is higher than the initial water level; -- indicates no data]

\begin{tabular}{|c|c|c|c|c|c|c|c|}
\hline \multicolumn{8}{|c|}{ Wells } \\
\hline \multicolumn{2}{|c|}{ DPW } & \multicolumn{2}{|c|}{$M W-18$} & \multicolumn{2}{|c|}{ G- 16} & \multicolumn{2}{|c|}{$M W-20$} \\
\hline$t$ & $\mathbf{s}$ & $t$ & $\mathbf{s}$ & $t$ & s & $t$ & $\mathbf{s}$ \\
\hline $0-4$ & -- & 50 & 0.067 & 17 & 0.01 & 1,760 & -0.11 \\
\hline 4 & 6.38 & 105 & .151 & 22 & .02 & 1,890 & -.08 \\
\hline 5 & 11.65 & 150 & .228 & 25 & .03 & 2,020 & -.09 \\
\hline 6 & 14.81 & 200 & .255 & 30 & .04 & 2,180 & -.15 \\
\hline 7 & 16.84 & 220 & .260 & 37 & .06 & 2,420 & -.12 \\
\hline 8 & 18.14 & 270 & .324 & 40 & .07 & 2,600 & -.20 \\
\hline 9 & 18.98 & 320 & .354 & 45 & .09 & 2,780 & -.17 \\
\hline 10 & 19.26 & 430 & .376 & 52 & .10 & 2,930 & -.19 \\
\hline $\begin{array}{l}20 \\
40\end{array}$ & $\begin{array}{l}21.19 \\
22.80\end{array}$ & $\begin{array}{l}530 \\
600\end{array}$ & $\begin{array}{l}.434 \\
.472\end{array}$ & $\begin{array}{l}60 \\
70\end{array}$ & $\begin{array}{l}.12 \\
.15\end{array}$ & -- & -- \\
\hline 60 & 23.60 & 680 & .509 & 80 & .17 & -- & -- \\
\hline 80 & 24.17 & 764 & .529 & 90 & .19 & -- & -- \\
\hline 100 & 24.62 & 825 & .536 & 110 & .23 & -- & -- \\
\hline 200 & 25.91 & 885 & .536 & 125 & .26 & $-\infty$ & -- \\
\hline 310 & 26.52 & 941 & .555 & 140 & .28 & -- & -- \\
\hline 400 & 26.71 & 1,000 & .556 & 190 & .31 & -- & -- \\
\hline 520 & 26.66 & 1,100 & .558 & 220 & .35 & -- & -- \\
\hline 610 & 26.75 & 1,200 & .563 & 290 & .36 & -- & -- \\
\hline 700 & 26.62 & 1,280 & .585 & 360 & .39 & -- & -- \\
\hline 850 & 26.46 & 1,380 & .601 & 430 & .43 & -- & -- \\
\hline 938 & 26.32 & 1,480 & .590 & 500 & .47 & -- & -- \\
\hline 1,046 & 26.10 & 1,620 & .546 & 600 & .55 & -- & -- \\
\hline 1,198 & 25.89 & 1,690 & .564 & 750 & .61 & -- & -- \\
\hline 1,263 & 25.69 & 1,780 & .534 & 950 & .64 & -- & -- \\
\hline 1,346 & 25.65 & 1,950 & .530 & 1,130 & .67 & -- & -- \\
\hline 1,593 & 25.25 & 2,060 & .549 & 1,280 & .73 & -- & -- \\
\hline 1,740 & 25.10 & 2,210 & .562 & 1,400 & .76 & -- & -- \\
\hline 1,847 & 24.85 & 2,380 & .513 & 1,580 & .76 & -- & -- \\
\hline 1,960 & 24.50 & 2,480 & .503 & 1,700 & .76 & -- & -- \\
\hline 2,080 & 24.30 & 2,580 & .503 & 1,850 & .75 & -- & -- \\
\hline 2,260 & 23.97 & 2,700 & .499 & 1,970 & .74 & -- & -- \\
\hline 2,397 & 23.88 & 2,900 & .555 & 2,130 & .78 & -- & -- \\
\hline 2,577 & 23.59 & 2,970 & .527 & 2,330 & .78 & -- & -- \\
\hline 2,777 & 23.32 & -- & -- & 2,480 & .81 & -- & -- \\
\hline 2,970 & 23.31 & -- & -- & 2,580 & .81 & -- & -- \\
\hline-- & -- & -- & -- & 2,680 & .83 & -- & -- \\
\hline-- & -- & -- & -- & 2,880 & .85 & -- & -- \\
\hline-- & -- & -- & -- & 2,970 & .85 & -- & -- \\
\hline
\end{tabular}




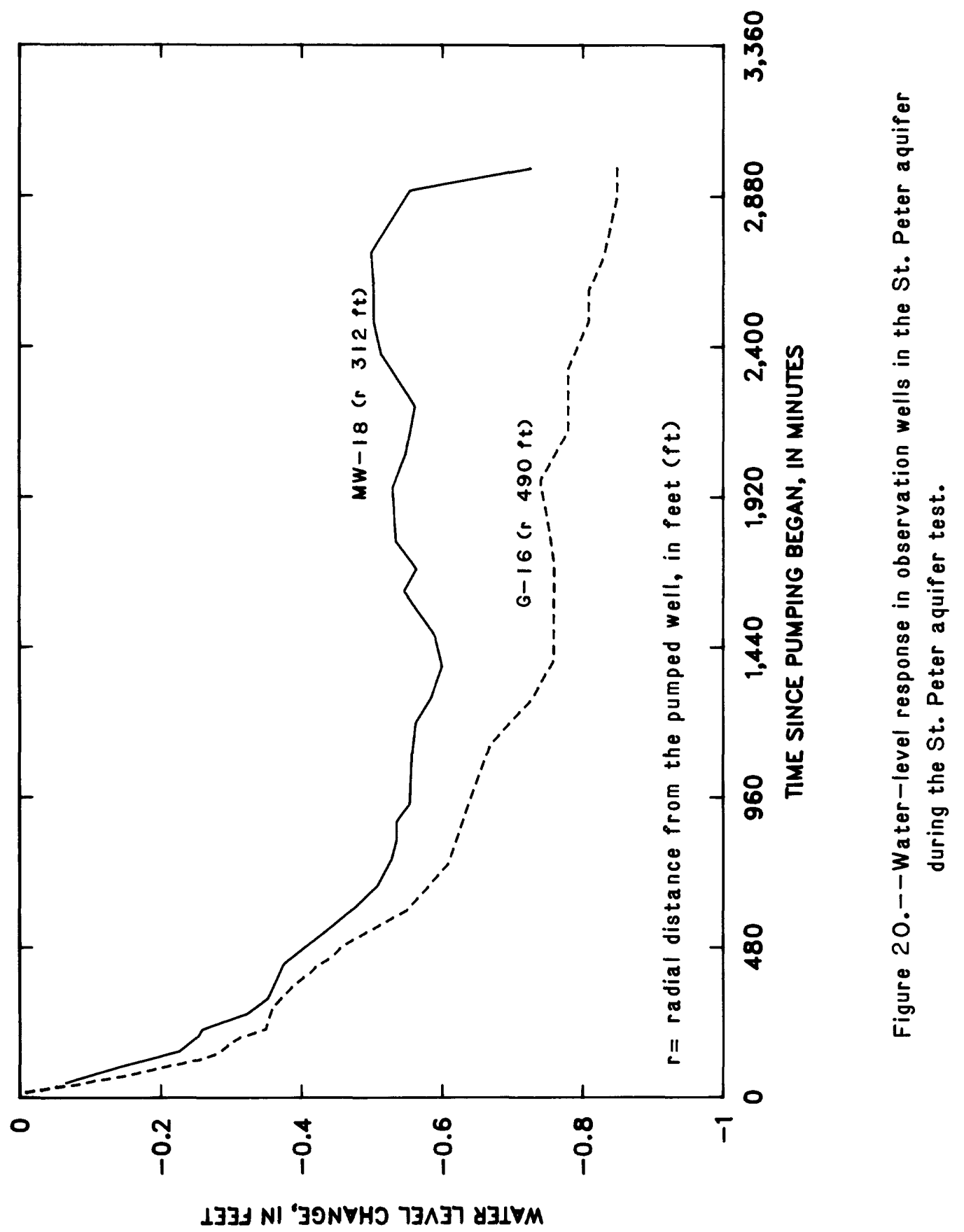


water-level rise is unknown but would seem to be related to well construction (compare well-construction information of wells MW-20 and MW-18 with well G-16 in table 1).

Water levels in well MW-18 were corrected for the regional rise in water level by assuming that the magnitude of the regional effect was the same in well MW-18 as it was in well MW-20. Because the water level in well G-16 did not rise during the pumping phase of the aquifer test (fig. 20), and because the water level at the end of the recovery period was essentially the same as the prepumping water level, it was assumed that the regional trend seen at wells MW-18 and MW-20 had no influence at well G-16; therefore, the well G-16 data were not adjusted.

Time-drawdown curves were constructed for wells MW-18, G-16, and the pumped well (DPW). These were matched to the family of type curves for a leaky artesian aquifer with no storage in the confining layer using the techniques of Hantush and Jacob (1955) (fig. 21). The match-point data represent the values of the four coordinate points-- $(u, v), u, s$, and t--obtained from the type curve and field-data curve at a point common to both curves when they match. For the Hantush-Jacob analysis, it is assumed that

1. Well discharge is at a constant rate, $Q$;

2. the pumped well is of infinitesimal diameter and fully penetrates the aquifer;

3. the aquifer has radial-vertical anisotropy;

4. the aquifer is overlain everywhere by a confining unit having uniform vertical hydraulic conductivity $\left(K^{\prime}\right)$ and thickness $\left(b^{\prime}\right)$;

5. the confining unit is overlain by an infinite constant-head plane source;

6. the hydraulic gradient across the confining unit changes instantaneously with a change in head in the aquifer;

7. flow is vertical in the confining unit; and

8. leakage in the confining unit is assumed to be generated within the aquifer so that in the aquifer no vertical flow results from leakage alone.

of these assumptions, only the second is not met or approximated in the St. Peter aquifer in the area where the observation wells are present. Correcting the drawdown data for partial penetration allows for the second assumption to be approximated.

Calculated values of horizontal hydraulic conductivity, transmissivity, and storativity for the St. Peter aquifer and leakage values through the Harmony Hill Shale Member are presented in table 7. At observation well G-16, estimated horizontal hydraulic conductivity was calculated to be $3.4 \mathrm{ft} / \mathrm{d}$, estimated transmissivity was $1,412 \mathrm{ft}^{2} / \mathrm{d}$, estimated storativity was $5.55 \times 10^{-4}$, and leakage was estimated to equal $2.35 \times 10^{-4}$ ( $\mathrm{ft} / \mathrm{d}$ )/ft (foot per day per foot). At observation well MW-18, calculated horizontal hydraulic conductivity was 3.7 $\mathrm{ft} / \mathrm{d}$, calculated transmissivity was $1,535 \mathrm{ft}^{2} / \mathrm{d}$, storativity was $1.88 \times 10^{-3}$, and leakage through the confining layer was calculated to be $6.31 \times 10^{-4}$ (ft/d)/ft. 

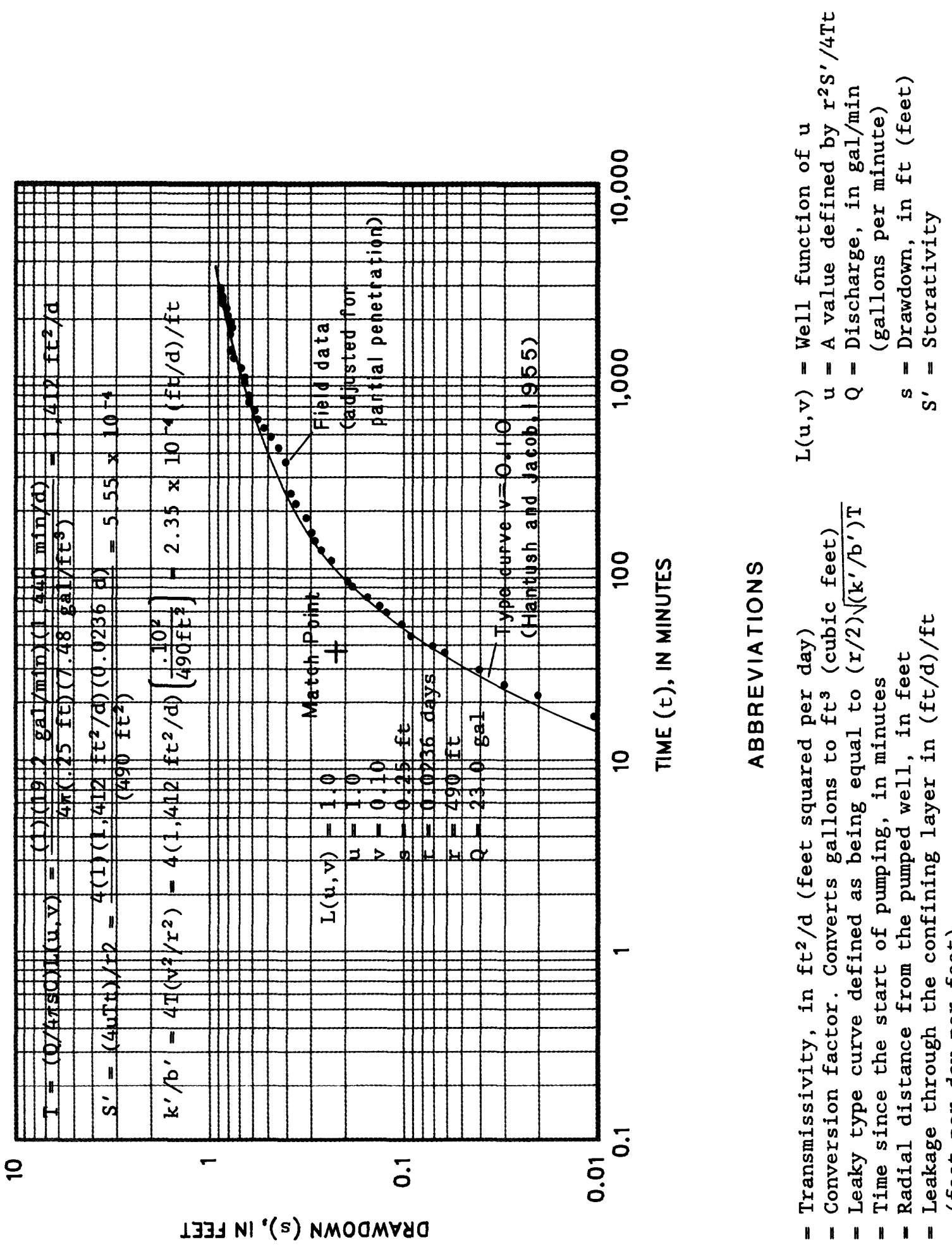

صב

苞出

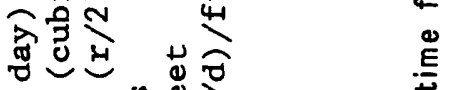

क

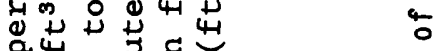

Q

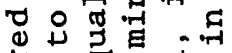

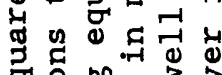

जo 3 रे

जी

要要通

( )

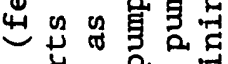

ट

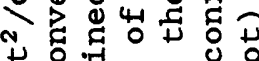

出 0 出目 0 。

द. वृ क्ष

द 0 व

. 용 क क

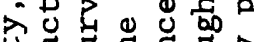

东出

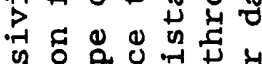

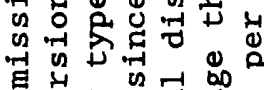

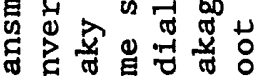

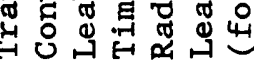

| | | || |

HUPH

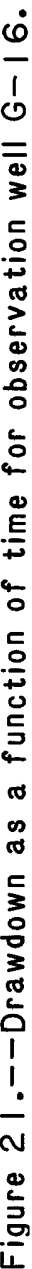

is 
Table 7.--Estimated horizontal hydraulic conductivity, transmissivity, storativity, and leakage through the Harmony Hill Shale Member of the Glenwood Formation from the St. Peter aquifer test of May 27-30, 1987

[ft/d, feet per day; $f t^{2} / d$, feet squared per day; $(f t / d) / f t$, feet per day per foot]

\begin{tabular}{cccccc}
\hline Method & Well & $\begin{array}{c}\text { Hydraulic } \\
\text { conduc- } \\
\text { tivity } \\
\text { (ft/d) }\end{array}$ & $\begin{array}{c}\text { Transmis- } \\
\text { sivity } \\
\text { (ft } / \mathrm{d})\end{array}$ & $\begin{array}{l}\text { Stora- } \\
\text { tivity }\end{array}$ & $\begin{array}{c}\text { Leakage } \\
{[(\mathrm{ft} / \mathrm{d}) / \mathrm{ft}]}\end{array}$ \\
\hline $\begin{array}{l}\text { Curve matching } \\
\text { (Hantush and } \\
\text { Jacob, 1955) }\end{array}$ & G-16 & 3.4 & 1,412 & $5.55 \times 10^{-4}$ & $2.35 \times 10^{-4}$ \\
\hline
\end{tabular}

Recovery phase data were analyzed and yielded virtually the same values as the drawdown data. Data from the test at the pumped well provided unrealistic values of transmissivity, storativity, and leakage, even after being corrected for partial penetration and well loss, and are not included in the report.

With the exception of two wells (MW-10 and MW-9), water levels in the wells screened in the Galena-Platteville aquifer showed no trends that could be related to pumping in the St. Peter aquifer. Water levels in well MW-10 declined steadily during the aquifer test, probably as the result of drawdown in the confining unit induced by pumping the st. Peter aquifer. Water levels in well MW-9, a water-table well $390 \mathrm{ft}$ southwest of the pumped well, declined beginning at approximately 1,800 minutes after the start of pumping and continued to decline through recovery to a final water level $0.55 \mathrm{ft}$ lower than the initial water level. The water level in well MW-8, screened at the top of the shale at approximately the same distance from the pumped well as well MW-9, rose slightly but steadily throughout the pumping and recovery phases of the test. The water level in well $\mathrm{MW}-8$ at the end of recovery was $0.11 \mathrm{ft}$ higher than before the test. This response of wells MW- 8 and MW-9 to pumping may be caused by leakage into the lower aquifer through a conduit, possibly a single fracture or a borehole open to both aquifers, that is in poor hydraulic connection with the screened interval at well MW-8. Well GW-44 is open to both aquifers (fig. 3) (Douglas Yeskis, U.S. Environmental Protection Agency, oral commun., 1987) and may be that conduit.

Based on water-level data at wells MW-8, MW-9, and MW-18, it is possible that part of the departure from the Theis-type curve in the St. Peter aquifer in this area is due to drainage through this possible conduit from the GalenaPlatteville aquifer through the Harmony Hill Shale Member. Drainage may have been induced by the increased head differences between the two aquifers brought on by pumping. 


\section{SUMMARY AND CONCLUSIONS}

The two primary residential-use aquifers in the study area are the GalenaPlatteville aquifer, consisting of the Galena and Platteville Groups, and the St. Peter aquifer in the St. Peter Sandstone. The Galena-Platteville aquifer consists of dolomites; the st. Peter aquifex consists of sandstone. The Galena-Platteville and St. Peter aquifers are separated by the Harmony Hill Shale Member of the Glenwood Formation, a semiconfining unit in this area. Ground-water flow in the dolomite is mainly through fractures and solution openings, although some water flow is through the porous matrix. Ground-water flow in the study area is from the area of the salvage yard to the Rock River. In the area of the salvage yard, water recharges from the water table to the base of the Galena-Platteville aquifer then through the semiconfining Harmony Hill Shale Member and into the st. Peter aquifer. In the vicinity of the Rock River, ground water discharges into the river.

Constant-discharge aquifer tests were conducted in both aquifers at the site. The Galena-Platteville aquifer test data were analyzed using the Boulton and streltsova-Adams (1978) double-porosity technique. The St. Peter aquifertest data were analyzed using the Hantush-Jacob (1955) method for a leaky artesian aquifer with no storage in the confining unit. Several conclusions were drawn from the aquifer-test data:

1. The Galena-Platteville aquifer is heterogeneous and anisotropic. The direction of maximum transmissivity in the dolomite aquifer is along the primary orientation of fractures and joints in the rock (N. $\left.60^{\circ} \mathrm{W}.\right)$.

2. In the Galena-Platteville aquifer, the average calculated transmissivity along the direction of preferential flow is $660 \mathrm{ft}^{2} / \mathrm{d}$, and specific yield ranges from 0.049 to 0.14 .

3. The estimated average transmissivity perpendicular to the direction of preferential flow is $490 \mathrm{ft}^{2} / \mathrm{d}$.

4. Estimated horizontal hydraulic conductivity for the St. Peter aquifer ranges from 3.4 to $3.7 \mathrm{ft} / \mathrm{d}$. Transmissivity of the St. Peter aquifer ranges from 1,412 to $1,535 \mathrm{ft}^{2} / \mathrm{d}$. The storativity of the St. Peter aquifer ranges from $5.55 \times 10^{-4}$ to $1.88 \times 10^{-3}$.

5. Leakage through the Harmony Hill Shale Member ranges from $2.35 \times 10^{-4}$ to $6.31 \times 10^{-4}(\mathrm{ft} / \mathrm{d}) / \mathrm{ft}$.

6. In addition to leakage through the shale, drainage from the GalenaPlatteville aquifer into the St. Peter aquifer may be occurring through discrete fractures or an open borehole through the Harmony Hill shale Member. 


\section{REFERENCES}

Boulton, N. S., and Streltsova-Adams, T. D., 1978, Unsteady flow to a pumped well in an unconfined fissured aquifer: Journal of Hydrology, v. 37, p. 349-363.

CH2MHi1l, Inc. and Ecology and Environment, Inc., 1984, Remedial action master plan, Byron Salvage Yard: U.S. Environmental Protection Agency, Chicago, Illinois, 73 p.

D'Appolonia Waste Management Services, 1984, Remedial action, Byron/Johnson site, Byron, Illinois: Feasibility study prepared for Illinois Environmental Protection Agency, Division of Land Pollution Control, Springfield, Illinois, $65 \mathrm{p}$.

Eagon, H. E., and Johe, D. E., 1972, Practical solutions for pumping tests in carbonate-rock aquifers: Ground water, v. 10, no. 4, p. 6-13.

Gilkeson, R. H. , Cartwright, Keros, Follmer, L. R., and Johnson, T. M., 1977, Contribution of surficial deposits, bedrock, and industrial wastes to certain trace elements in ground water in Proceedings of the 15th Annual Symposium on Engineering Geology and Soil Engineering, Pocatello, Idaho, April 5, 1977: Idaho Department of Transportation, p. 17-38.

Hantush, M. S., and Jacob, C. E., 1955, Nonsteady radial flow in an infinite leaky aquifer: American Geophysical Union Transactions, v. 36, no. 1, p. 95-100.

LeGrand, H. E., and stringfield, V. T., 1971, water levels in carbonate rock terranes: Ground Water, v. 9, no. 3, p. 4-10.

Piskin, Rauf, 1976, Report on disposal of toxic wastes at Byron salvage Yard: Illinois Environmental Protection Agency, Division of L/NPC, Land Unit, Springfield, Illinois, 197 p.

Sargent and Lundy, Inc., and Dames and Moore, Inc, , 1975, Fault specific geotechnical investigations, Byron Station: Engineering Report, $40 \mathrm{p}$.

Walton, W. C., 1962, Selected analytical methods for well and aquifer evaluation: Illinois State Water Survey Bulletin 49, $81 \mathrm{p}$.

---- 1978, Comprehensive analysis of water-table aquifer test data: Ground water, v. 16, no. 5 , p. 311-317.

Willman, H. B., Atherton, Elwood, Buschbach, T. C., Collinson, Charles, Frye, J. C., Hopkins, M. E., Lineback, J. A., and Simon, J. A., 1975, Handbook of Illinois stratigraphy: Illinois state Geological survey Bulletin 95, 261 p. 


\section{GLOSSARY}

Aquifer.--A formation, group of formations, or part of a formation that contains sufficient saturated permeable material to yield significant quantities of water to wells and springs.

Confining unit.--A rock layer of low permeability lying directly above or below an aquifer. Its hydraulic conductivity may range from nearly zero to some value distinctly lower than that of the aquifer.

Hydraulic conductivity.--The rate at which water of a prevailing viscosity is transmitted through a cross section of unit area of aquifer under a unit hydraulic gradient.

Hydrogeologic unit.--A formation, part of a formation, or a group of formations in which there are similar hydrologic characteristics allowing for combining into aquifers or confining units.

Storage coefficient.--The volume of water an aquifer releases from or takes into storage per unit surface area of the aquifer per unit change in head. In an unconfined aquifer, the storage coefficient is called the specific yield. In a confined aquifer, the storage coefficient is called the storativity.

Transmissivity.--The rate at which water of a prevailing viscosity is transmitted through a unit width of aquifer under a unit hydraulic gradient. 


\title{
APPENDIX 1
}

\author{
RESULTS OF GEOPHYSICAL LOGGING
}

Natural-gamma logs were run in 10 of the wells in the study area (MS-2, GW-16, GW-42, MW-10, MW-11, MW-18, MW-20, PC-2, DPW, and SPW) for the purpose of stratigraphic correlation. Natural-gamma logs measure the natural-gamma radiation emitted by the rock. Since the presence of natural radiation generally is a function of the clay content of the rock, it was anticipated that natural-gamma logs would pinpoint the location of the Harmony Hill shale Member of the Glenwood Formation and the St. Peter Sandstone.

Lithology was determined from a 2-inch-diameter core from well MW-20 and compared to the natural-gamma log (fig. 4). As figure 4 shows, there are essentially three beds that can be readily identified within the GalenaPlatteville-Glenwood-St. Peter sequence. The uppermost bed (bed 1) is the shale layer in the dolomite, which produces a distinct peak in the naturalgamma logs. The second bed is the Harmony Hill Shale Member, which produces a second peak on the natural-gamma logs. The third bed is the st. Peter Sandstone at the base of the Glenwood Formation, which display little response on the log.

Once the beds were identified on the natural-gamma log of well MW-20, the next step was to correlate them with other wells. Lines of section $A-A^{\prime}$ and $B-B^{\prime}$ were drawn through the study area (fig. 6) and the logs for the wells along those lines were plotted (figs. 22 and 23). As can be seen in figures 22 and 23, the beds found at well MW-20 can be correlated throughout the study area where data are present. The natural-gamma logs in figure 22 demonstrate a southerly component to the dip of the bedrock in the study area along section $A-A^{\prime}$. The Harmony Hill shale Member and the st. Peter sandstone are at higher altitudes in the northern part of the study area than in the southern part of the study area. The logs used to construct section B-B' are insufficient to determine the east-west component to the dip of the bedrock.

Though the beds can be correlated from well to well, they are not readily apparent at some locations. In well SPW (fig. 23), peaks in the natural-gamma log are present that do not exist at other locations. The natural-gamma log and the caliper log for well SPW were compared to explain the cause of the anomalous peaks (fig. 12). As figure 12 shows, the parts of the well that widen and have an irregular diameter correspond to zones with an increased clay content. The presence of clays in the broken parts of the dolomite suggests that post-depositional, post-tectonic infilling of fractures by clays is obscuring the original stratigraphy at well SPW.

In an effort to determine the location and orientation of fractures and solution openings in the bedrock, three-arm caliper logs were run on wells GW-42, GS-16, SPW, and DPW and acoustic televiewer logs were run on wells GW-16, GS-42, and the uncased part of well DPW. Three-arm caliper and televiewer logs indicate that the St. Peter Sandstone is relatively free of fractures. Caliper and televiewer logs of the Galena and Platteville Groups show a number of fractures and solution openings in the dolomite. In the two wells (GW-16 and 


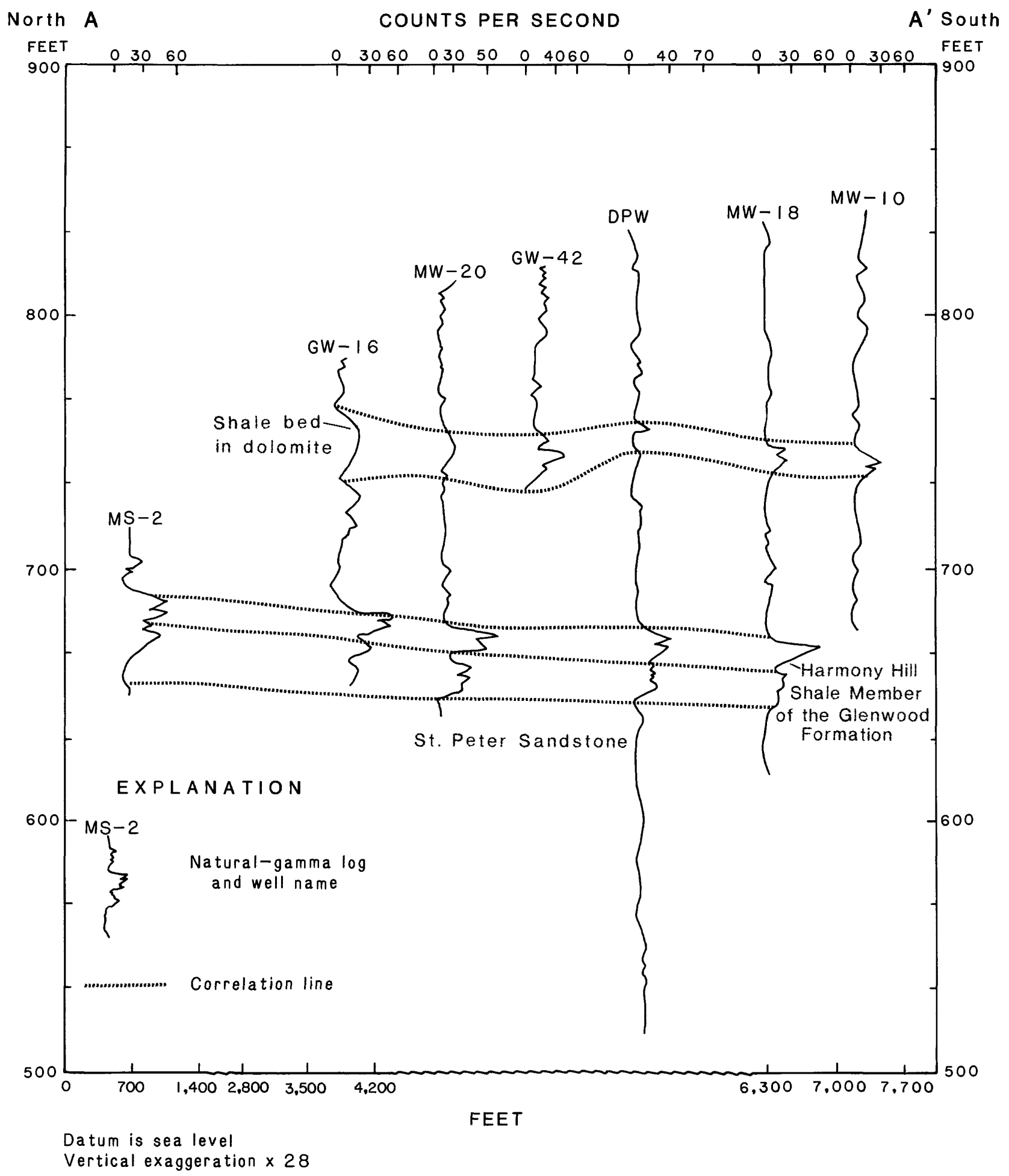

Figure 22.--Correlation of natural-gamma logs along line of section $A-A^{\prime}$. 


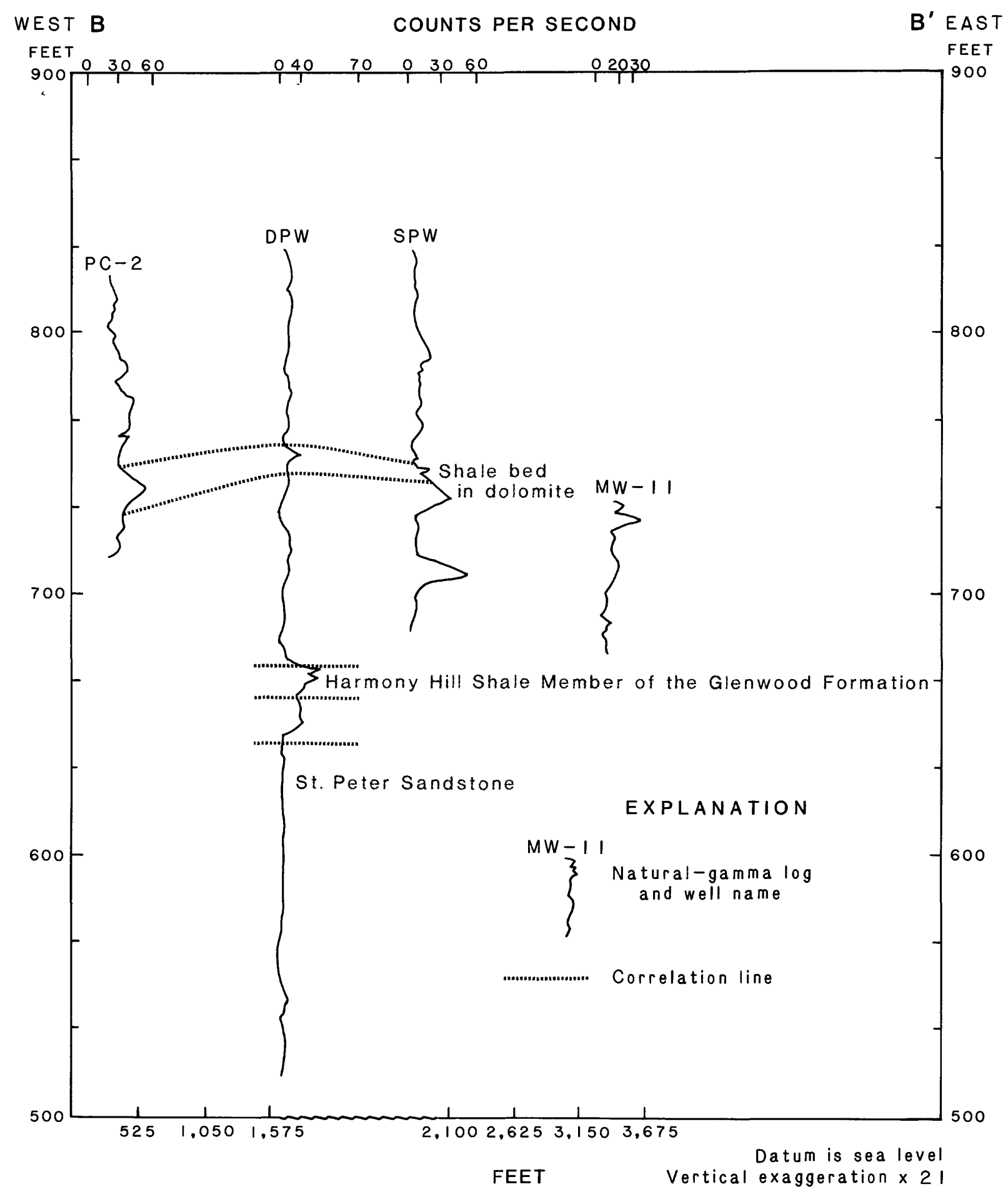

Figure 23.--Correlation of natural-gamma logs along line of section B-B'. 
GS-42) for which acoustic televiewer data of the dolomite exist, fractures show a horizontal or near-horizontal orientation. This is not meant to imply that vertical fractures do not exist, only that they were not detected by the televiewer in these wells.

Neutron logs were run on 11 wells (all wells in which natural-gamma logs were run plus well $\mathrm{MW}-16$ ) in the study area. Because neutron logs measure the hydrogen content in the surrounding rock, and because the hydrogen content of the rock is related to its saturated porosity if no hydrated minerals are present, it was anticipated that the neutron logs would provide estimates of rock porosity.

Rock samples from the well MW-20 core were analyzed for porosity, bulk density, grain density, and bulk specific gravity by immersion in distilled water and using displacement procedures (Vincent Gutowski, Eastern Illinois University, written commun., 1987). The results of the laboratory-determined porosity analyses on the rock samples are presented in table 8. The porosity of the Galena and Platteville dolomites ranges from 8 to 15 percent and usually is in the 8 to 10 percent range. Porosity in the St. Peter Sandstone is approximately 14 percent based on the measurement made from one sample from a depth of $185.5 \mathrm{ft}$.

Table 8.--Laboratory determined values of porosity, bulk density, grain density, and bulk specific gravity for rock samples at observation well MW-20

[Vince Gutowski, Eastern Illinois University, written commun., 1987; $\mathrm{g} / \mathrm{cm}^{3}$, grams per cubic centimeter]

\begin{tabular}{cccccc}
\hline $\begin{array}{c}\text { Depth } \\
\text { below } \\
\text { land } \\
\text { surface } \\
\text { (feet) }\end{array}$ & \multicolumn{1}{c}{$\begin{array}{c}\text { Geologic } \\
\text { unit }\end{array}$} & $\begin{array}{c}\text { Porosity } \\
\text { (percent) }\end{array}$ & $\begin{array}{c}\text { Bulk } \\
\text { density } \\
(\text { g/cm })^{2}\end{array}$ & $\begin{array}{c}\text { Grain } \\
\text { density } \\
\left(\mathrm{g} / \mathrm{cm}^{3}\right)\end{array}$ & $\begin{array}{c}\text { Bulk } \\
\text { specific } \\
\text { gravity } \\
\left(\mathrm{g} / \mathrm{cm}^{3}\right)\end{array}$ \\
\hline 23.0 & Galena-Platteville & 8 & 2.50 & 2.43 & 2.49 \\
38.0 & Galena-Platteville & 10 & 2.51 & 2.41 & 2.51 \\
57.0 & Galena-Platteville & 9 & 2.51 & 2.42 & 2.58 \\
76.0 & Galena-Platteville & 9 & 2.52 & 2.44 & 2.51 \\
78.0 & Galena-Platteville & 9 & 2.50 & 2.41 & 2.51 \\
103.0 & Galena-Platteville & 10 & 2.49 & 2.39 & 2.47 \\
130.0 & Galena-Platteville & 15 & 2.33 & 2.18 & 2.24 \\
140.5 & Galena-Platteville & 8 & 2.46 & 2.39 & 2.46 \\
164.5 & Glenwood & 17 & 2.12 & 1.95 & 1.99 \\
185.5 & St. Peter & 14 & 2.22 & 2.07 & 2.11 \\
\hline
\end{tabular}


Comparison of the neutron-log reading for well $\mathrm{MW}-20$ with the measured porosity of the rock for selected intervals below the water level in well MW-20 (fig. 24) shows that there is a relation between the two. As figure 24 shows, the higher the porosity of the rock, the fewer the neutrons that are detected. Attempts to identify a mathematical relation between the neutron-log response and the rock porosity proved unsuccessful. Because there is no exact relation between porosity and neutron-log response, the usefulness of this log in determining the porosity of the Galena and Platteville dolomites is limited.

The most likely reason for the poor correlation between neutron-log response and porosity in the dolomite deposits is the widespread presence of clay minerals and shale partings in the dolomite. Water incorporated into the structure of the clay mineral and water in the pore spaces between clay particles would produce a response on the neutron log that was not attributable to laboratory-determined porosity values. Laboratory-determined values of porosity for shale deposits tend to be inaccurate because of the long times required to saturate the shale samples. This hypothesis is supported by the neutron-log response opposite the Harmony Hill Shale Member and the argillaceous zones associated with bed 1. Neutron logs from other wells show that the hydrogen content of the rock in these deposits is high even though the laboratory-determined porosity is low.

Estimates of fracture porosity were attempted by correlating zones of known fractures with neutron-log response. It was found that no significant change occurred in the neutron-log readings opposite fractures that had not been infilled with clay. The absence of a neutron-log response to fractures indicates that the volume of water in the fractures is too small to be detected by the logging device and that little secondary porosity is present in the Galena and Platteville dolomites. 

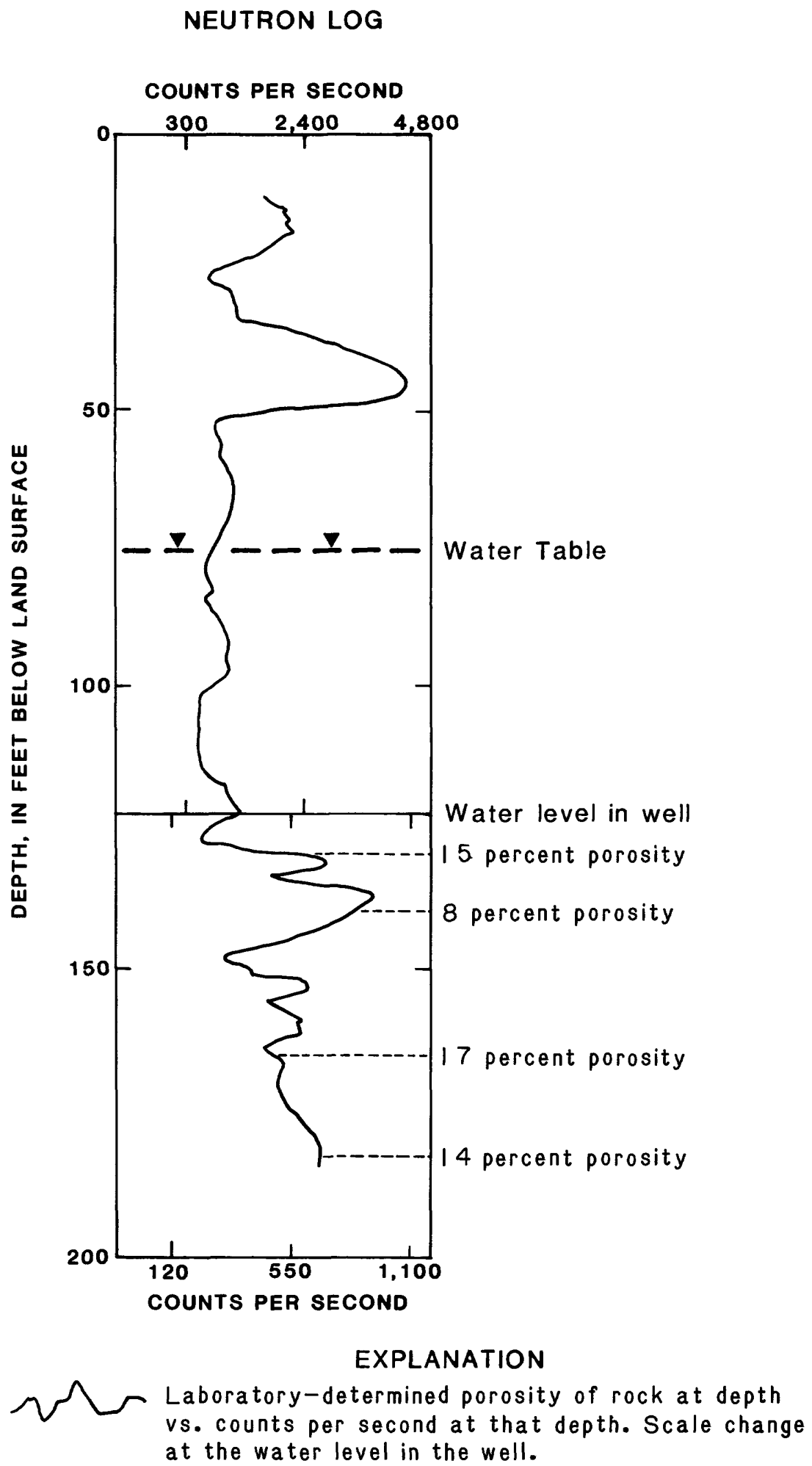

Figure 24.--Neutron-log response compared to percent porosity for well MW-20. 